Boston University School of Law

Scholarly Commons at Boston University School of Law

Faculty Scholarship

$11-2016$

Accounting for Rising Corporate Profits: Intangibles or Regulatory Rents?

James Bessen

Follow this and additional works at: https://scholarship.law.bu.edu/faculty_scholarship

Part of the Law and Economics Commons, and the Law and Politics Commons 
ACCOUNTING FOR RISING CORPORATE PROFITS: INTANGIBLES OR REGULATORY RENTS?

\author{
Boston University School of Law \\ Law \& Economics Working Paper No. 16-18
}

November 9, 2016

James Bessen

Boston University School of Law

This paper can be downloaded without charge at:

http://www.bu.edu/law/faculty-scholarship/working-paper-series/ 


\title{
Accounting for Rising Corporate Profits: Intangibles or Regulatory Rents?
}

\author{
By James Bessen \\ Boston University School of Law
}

November 2016

\begin{abstract}
Since 1980, US corporate valuations have risen relative to assets and operating margins have grown. The possibility of sustained economic rents has raised concerns about economic dynamism and inequality. But rising profits could come from political rents or, instead, from returns to investments in intangibles. Using new data on Federal regulation and data on lobbying, campaign spending, $\mathrm{R} \& \mathrm{D}$, and organizational capital, this paper finds that both intangibles and political factors account for a substantial part of the increase in profits, but since 2000 political factors are more important. A difference-in-differences analysis finds that major expansions of regulation increase profits significantly.
\end{abstract}

Key words: Regulation, intangibles, economic rents

JEL: D72, L1, E22

Thanks to Bob Bone, Ian Hathaway, Keith Hylton, Patrick McLaughlin, Mike Meurer, Brian Roberts, Alex Tabarrok, Kathy Zeiler, and participants in seminars at BU and University of Texas for comments and advice. Thanks to Stefanie Weigmann for research on regulatory histories. 


\section{Introduction}

Corporate valuations in the US have seen a sustained rise relative to assets over the last three decades; corporate profits have seen a similar sustained rise relative to sales. Figure 1 shows the log of aggregate Tobin's Q, the ratio of firm market value to firm assets, for the nonfinancial corporate sector. The black line (smoothed and dashed) shows the log ratio of aggregate firm value over firm assets from the US System of National Accounts. ${ }^{1}$ The gray line shows the aggregate estimate of $\log$ Tobin's Q for a large sample of publicly listed firms described below. ${ }^{2}$ Both lines show a substantial rise in corporate valuations relative to tangible assets since 1980. Figure 2 shows measures of current profit flows. The black line, also drawn from the National Accounts, represents the ratio of the net operating surplus to gross value added for the corporate sector (nonfinancial and financial). The gray line is the ratio of aggregate operating income after depreciation to revenues for firms publicly listed in the US. Again, both series show a substantial rise, in this case beginning around 1990 .

Does this rise signal that US firms are extracting greater economic rents and, if so, what does that imply for economic dynamism and inequality? The implications are potentially troubling. A large literature associates regulatory rents with diminished dynamism because of wasteful rent seeking (Tullock 1967, Posner 1975) that creates barriers to entry (Olson 1982) or diverts talent from productive endeavors (Murphy, Shleifer, and Vishny 1991). In addition, Stiglitz (2012) attributes much of the inequality in our economy to

\footnotetext{
${ }^{1}$ Aggregate firm value (total liabilities + inventories - current assets) over firm assets (nonfinancial assets excluding intellectual property products plus equity and investment fund shares) using data from the Bureau of Economic Analysis, see http://www.bea.gov/national/nipaweb/Ni_FedBeaSna/Index.asp.

${ }^{2}$ Estimates of Tobin's Q derived from firm microdata are typically higher than estimates derived from national accounts because of accounting and other differences. See Piketty and Zucman (2014).
} 
political rent seeking while Piketty (2014) sees rising corporate valuations leading to greater wealth inequality and the rise of a rentier society.

Yet not all rents arise from political rent seeking activity nor do all rents imply social waste. For example, firms can earn rents on innovations. These rents constitute an important incentive to encourage investment in innovation. Generally, firms capture returns on intangible investments as rents, that is, as supra-normal profits. This includes returns on R\&D, on "brand capital," and on organizational investments.

This paper explores the roles of intangible investments and regulatory rents in accounting for the recent rise of corporate valuations and profits. Finding an economically substantial association between regulation and profits, I further explore the causal nature of this link and I consider other factors such as changes in industry concentration.

Any attempt to understand the significance of economic rents must account for the source and nature of the rents for several reasons. First, if economic rents simply reflect returns to growing investments in new technology, they might signal greater economic dynamism, not less. ${ }^{3}$ Similarly, to the extent that economic inequality arises from rents, the nature of those rents matters. The rise in the capital share of corporate income (Figure 2) corresponds to a fall in labor's share of income, one indicator of inequality (Piketty 2014). Again, the rise in markups might not be too troubling if it simply represents returns to investments in technology.

Also, much of the increase in wage dispersion has been attributed to differences between firms or between establishments (Song et al. 2015). Furman and Orszag (2015) propose that rising corporate rents are shared with workers at affected firms, leading to

\footnotetext{
${ }^{3}$ In patent race models (Loury 1979; Dasgupta and Stiglitz 1980), R\&D spending can, in some circumstances, exceed the socially optimal level. But while such wasteful spending might not be socially optimal, it nevertheless leads to increased dynamism, perhaps excessively so.
} 
rising inter-firm wage differences. But if firm rents are rising primarily because of greater investments in new technology, then pay might rise at those firms because of greater demand for technology-specific skills. Indeed, Dunne et al. (2004) find that a significant fraction of the growth in the dispersion of wages between plants is accounted for by differences in plant investments in computer technology. The story clearly means something different if firm rents are rising primarily because of regulatory capture.

\section{Accounting for the sources of rents}

Broadly, the aim of this paper is to account for the relative contributions of corporate rents from three sources: returns on intangibles, industry concentration, and government regulation. To do this accounting, I use a well-established empirical framework for estimating the contribution of intangible investments to firm market value. Beginning with Griliches (1981), numerous studies have used regressions on Tobin's Q or firm market value to estimate the economic value of intangibles including R\&D (Cockburn and Griliches 1988; Hall 1993; Lev and Sougiannis 1996), advertising and marketing (Fullerton and Lyon 1988, Villalonga 2004), union rents (Salinger 1984), patents (Hall, Jaffe, and Trachtenberg 2005; Bessen 2009), and organization capital (Lev and Radhakrishnan 2005; Eisfeldt and Papanikolaou 2013). Using a large sample of firms listed on US public exchanges from 1970 through 2014, I use this approach to estimate the association between firm market values and stocks of R\&D, advertising and marketing expenditures, and organizational investments measured via sales, general, and administrative expense. I also use a regression analysis to test the relationship between firm operating margins and these intangibles.

This framework can be expanded to include measures of industry concentration and government-created political rents. In the analysis below, I use standard measures of 
concentration such as the share of revenues going to the top four firms in 4-digit NAICS industries.

Measuring regulatory rents

It is less obvious how to measure rents arising from governmental decisions. A variety of government actions can generate rents. Sometimes government creates exclusive markets for assets such as wireless spectrum or oil leases. Patents create market power, as do entry barriers that arise from costly regulation (Dean and Brown 1995). Antitrust policy affects industry concentration, rate setting in regulated markets can create rents, as do government payments in the form of contracts, tax breaks, subsidies and bailouts.

I consider two approaches for gauging rents that arise from government regulation: measuring investments in corporate political activity and measuring the extent of industryspecific regulation. Two measures of corporate political activity are lobbying expenditures and election campaign contributions. De Figuieredo and Richter (2014) review the literature on the impact of lobbying, finding effects across a wide range of policy areas. Another literature explores the association between legislative voting and campaign contributions. Ansolabehere, de Figuieredo, and Snyder (2003) review this literature, finding little evidence that campaign contributions influence voting. They conclude that this spending might be viewed primarily as a consumption good. However, legislative votes are only one channel through which firms influence regulation; campaign spending and lobbying might also affect the drafting of legislation (firms may benefit from the particular wording of laws), agency rulemaking, rate setting, and other regulator actions. Other empirical research suggests that some corporate political activity is directed to benefit managers rather than the firm, that is, 
there is an agency problem (Hochberg et al. 2009; Yu and Yu 2011; Werner and Coleman, 2015).

Yet a variety of evidence shows numerous ways that rent seeking activities seem to pay for the firm. Case studies have found that corporate political activity is associated with favorable tax treatment (Richter, Samphantharak, and Timmons 2009; Alexander, Mazza, and Scholz 2009), regulatory rate setting (Bonardi et al., 2006), tariffs (Mayda et al., 2010), government contracts (Goldman et al., 2013), and bailouts (Duchin and Sosyura 2012). Moreover, recent research finds associations between corporate valuations and profits and measures of lobbying activity and corporate campaign contributions (Cooper, Gulen, and Ovtchinnikov 2010; Hill et al. 2013; Chen, Parsley, and Yang 2015), including possibly corrupt activity (Borisov, Goldman, and Gupta 2016). However, Hadani and Schuler (2012) find a negative relationship between corporate political activity and firm market performance. Moreover, this literature has largely not explored the causal relationship between corporate political activity and firm performance; an exception is Werner and Roberts (2015) who use an instrumental variable estimation.

In any case, while campaign spending and lobbying expenditures might be useful measures of rent seeking activity, they are likely incomplete measures of the ability of firms to earn rents from government for several reasons. First, reporting requirements have changed over time as well as the restrictions on spending. ${ }^{4}$ Second, most firms do not spend in either category. ${ }^{5}$ This does not mean, however, that most firms do not earn government-

\footnotetext{
${ }^{4}$ The requirements on reporting of campaign spending and spending limits have been affected by a number of agency and legislative changes as well as Supreme Court decisions affecting campaign spending; data on lobbying was only reported following the Lobbying Disclosure Act of 1995.

${ }^{5}$ In the Compustat sample of publicly listed firms in 2014, 18\% spent on lobbying while 11\% made PAC campaign contributions. In addition to being incomplete, this raises concerns about selection bias.
} 
created rents. The full range of rent seeking activities is much broader than US campaign spending and the use of registered lobbyists: firms pursue favorable decisions from regulators on rate setting or leases on Federal property or tax treatments, they challenge regulatory rules and decisions in court, they make extensive investments in order to gain regulatory approval (e.g., clinical drug trials), they hire former regulators, and they may make major changes in business strategy in order to capture regulatory rents (Posner 1975). Moreover, firms pursue rents not only from the US Federal government, but also from state, local, and foreign jurisdictions. Finally, even if we could measure all of these rent-seeking activities, these are only inputs to rent generation; firms may earn rents from government actions even when these rents are not the direct result of the affected firm's political activity.

The complexity of regulation

Ideally, we would like to measure the rent-generating potential of government regulations affecting different industries. I propose that the extent or complexity of regulation might reflect its rent-generating potential. Below I describe Regdata (Al-Ubaydli and McLaughlin 2015), a data source that provides industry-weighted word counts for each part and title of the Code of Federal Regulations for each year. These data might proxy for the rent-generating potential of regulation and hence might serve to capture the extent to which the rise in firm profits is associated with government regulation.

Whether these data actually serve this purpose, however, is an empirical question. There are theoretical reasons both for and against my proposed use. ${ }^{6}$ There are two reasons why more complex regulation might be associated with greater rents. First, regulation might become more complex as firms exert greater effort at rent seeking. At least since Mancur

${ }^{6}$ See Peltzman (1989) for an overview of the theory of regulation. 
Olson (1982, pp. 69-73), economists have identified several reasons why growing complexity might reflect rent seeking: ${ }^{7}$ rent seekers might exact special provisions and exceptions to regulations; because the general public has limited interest, special interests may succeed with more complex regulation; regulation may become more complex as firms find loopholes or ways to evade prior regulation, requiring new regulation. In all these cases, significant potential rents would encourage firms to contest the regulations aggressively, expanding the extent of regulation and making it a proxy for rent seeking effort.

Second, the complexity of regulation might itself facilitate rent extraction (McCarty 2013, Drutman 2015). For example, more complex regulation might make regulators more dependent on industry knowledge and expertise, facilitating industry influence. More complex regulation can serve as an entry barrier, providing rents to incumbents and larger firms (Nitzan, Procaccia, and Tzur 2013). ${ }^{8}$

On the other hand, there are reasons to think that more extensive regulation might be associated with lower rents. In one view, regulators develop new regulations in order to fix market failures (as in Pigou 1920), including monopoly rents. Also, the "tollbooth" view of regulation (McChesney 1987; Djankov et al. 2002) sees regulation imposing costs on industry for the benefit of bureaucrats and politicians; that is, regulators extract rents earned by firms. In this account, regulation also decreases rents, but with different motivation.

While these different views are not necessarily mutually exclusive, they do imply that regulation and rents could be either positively or negatively correlated. Incorporating this

\footnotetext{
7 See also Kearl 1983; Quandt 1983; Krueger and Duncan 1993.

${ }^{8}$ For example, Philip Morris supported legislation to regulate tobacco by the FDA, perhaps in order to gain an advantage against smaller rivals and potential entrants (James Flanigan, "Philip Morris' Tactic: FDA

Regulation," Los Angeles Times, April 22, 2001). The evidence on whether regulation tends to reduce entry in general is mixed. See Goldschlag and Tabarrok (2016) but also Bailey and Thomas (2015).
} 
index of regulation into the regression analysis along with measures of campaign spending and lobbying expenditures, I find that all are positively associated with Tobin's Q and firm operating margins but the association with the regulation index is particularly significant. However, this association must be interpreted carefully because it is not clear which way causality flows. As above, regulators might develop new regulations in order to fix market failures, including monopoly rents. In this case, regulations would be developed in response to economic rents rather than creating rents. To distinguish between these two effects, I also conduct several causality tests below.

\section{Estimation strategy}

Specification

Viewing firm value as the present value of future profits, Hayashi (1982) provides a formal model relating firm value to the current value of capital stocks. Hayashi and Inoue (1991) and Hall (1993) extend this model to multiple capital stocks that might include both tangible capital and stocks of intangibles. I use a simplified variation of their models and include stocks of not only capitalized investments in productive intangibles, but also capitalized investments in rent seeking.

I assume that profits are a function of an aggregate capital stock for firm $j$ at time $t$

$$
K_{j t}=\sum_{i} \gamma_{i} k_{i j t}
$$

where the $\gamma_{i}$ coefficients represent the relative profit-generating potential of different types of capital stocks, $k_{i j t}$ (Hall 1993). Let $i=0$ represent tangible capital and normalize $\gamma_{0}=1$. Assuming for simplicity that firms optimize variable inputs at each point in time, the production function has constant returns to scale, and there are adjustment costs to 
investment, then Tobin's Q, defined as firm market value over the current value of tangible capital, is equal to (see Appendix),

$$
Q_{j t} \equiv \frac{V_{j t}}{p_{0 t} k_{0 j t}}=q_{t}\left(1+\gamma_{1} \frac{k_{1 j t}}{k_{0 j t}}+\gamma_{2} \frac{k_{2 j t}}{k_{0 j t}}+\cdots\right)
$$

Where $V$ is firm value and $p$ is the user cost of capital. Hayashi calls the variable $q_{t}$ "marginal q;" it is assumed to be approximately equal to 1 and, given competitive capital markets, it is equal across firms at any given time.

This simple equation captures two intuitions. One intuition is Tobin's original insight that the market value of a firm is related to the replacement cost of its assets. In a competitive market, firms will add capacity (either new entrants or existing firms) at the replacement cost of capital, driving prices down until, in long run equilibrium, the discounted stream of expected future profits (market value) equals the cost of those assets. However, because of adjustment costs, the long run equilibrium is not reached immediately. Instead, marginal $q$ differs from unity, exceeding 1 when the capital stock is below the equilibrium level, less than 1 when there is excess capacity. Marginal $q$ captures variation in firm value associated with the business cycle and also with shocks such as globalization. The second intuition is that intangibles and favorable regulation create supra-normal profits reflected in a market value that exceeds that of a competitive firm.

I assume that disturbances are multiplicative so that, taking logarithms,

$$
\log Q_{j t}=\log \left(1+\gamma_{1} \frac{k_{1 j t}}{k_{0 j t}}+\gamma_{2} \frac{k_{2 j t}}{k_{0 j t}}+\cdots\right)+\sum_{T} \delta_{T} \cdot I(t=T)+\varepsilon_{i j t}
$$


where $I$ is an indicator function. I estimate this equation using nonlinear least squares. ${ }^{9}$ The coefficients $\gamma_{i}$ tell us about the relative importance of the different capital stocks for generating profits.

However, other factors could contribute to a sustained rise in profits in some industries. Firms might have greater market power in more concentrated industries, generating sustained higher profits. Although regulation might create market power as noted above, other independent factors might also create market power that could raise Tobin's Q such as changes in antitrust policy, financial innovations facilitating mergers, or new technologies that generate strong network effects. To test for these possibilities I include an industry concentration measure in some estimates. Also, investors might demand higher risk premiums for more volatile companies, rewarding them with lower stock prices. Declining volatility might also contribute to rising values of Tobin's Q. I also estimate specifications including a measure of stock volatility below.

A comparable regression can be found using firm operating margins as the dependent variable. Because corporate valuations reflect investors' expectations of future profits, current profits should exhibit similar associations with intangibles and regulation, albeit possibly with higher standard errors. Assuming a linear homogeneous profit function (see Appendix), current profits can be written as the sum of returns on the various capital stocks,

$$
\pi_{j t}=\frac{\partial \pi}{\partial K} \sum_{i} \gamma_{i} k_{i j t}
$$

${ }^{9}$ See Hall (1993) and Bessen (2009) for discussion of other specifications. Note that the Taylor series approximation of $\log (1+x) \approx x$ for $x \approx 0$ does not work well for the data here because the implied values of $\mathrm{x}$ are too large. 
recognizing that the rate of return on the aggregate stock will change over time. Using time dummies and adding an error term, operating margins can then be written as

$$
\frac{\pi_{j t}}{S_{j t}}=\sum_{i} \beta_{i} \frac{k_{i j t}}{S_{j t}}+\sum_{T} \delta_{T} \cdot I(t=T)+\varepsilon_{i j t}
$$

This equation can be estimated using OLS.

\section{Data}

Sample

The main sample consists of Compustat firms traded on US exchanges between 1970 and 2014. I exclude firms that are missing data on market value, sales, and assets. For the regression analyses shown in the paper, I also exclude the 1 percent tails of the dependent variable to counter measurement error at the extremes.

The calculation of Tobin's Q requires estimating the replacement cost of the firm's capital. For non-financial firms this estimate is based substantially on the firm's investments in plant and equipment. Many financial firms do not report plant and equipment and the meaning of their capital assets is mainly financial in any case. I exclude these financial firms from the Tobin's Q analysis, leaving a sample of 193,148 firm-year observations in an unbalanced panel; financial firms are included in the analysis of operating margins.

Because regulation data is central to the analysis, I also restrict the sample to firms in industries that are assigned a regulation index. As described below, the sections of the Code of Federal Regulation are assigned weights for different industries using a computer algorithm. In some cases, sampling variance makes the industry match unreliable and the 
industry is not assigned a regulation index in Regdata. ${ }^{10}$ At the 3-digit industry level, 31\% of the firm-year observations lack a regulation index. In the analysis reported below, I exclude these observations, leaving a sample of 133,198. I repeated the regressions including them but coding the regulation index to zero. The results were quite similar except that the coefficient of the regulation variable was attenuated, as expected.

For the regressions on firm operating margins, I include the financial firms. However, for these analyses I thought it appropriate to exclude startups that are in a predominately research phase, prior to meaningful "regular" sales. I excluded firm where research and development costs exceeded half of net revenues, leaving a sample of 135,968 firm-year observations.

\section{Variables}

Key variables are defined as follows:

The market value of the firm consists of the sum of all the claims on the firm, namely, the sum of the value of the common stock, the preferred stock (valued by dividing the preferred dividend by Moody's Index of Medium Risk Preferred Stock Yields), long term debt adjusted for inflation, and short term debt net of current assets. While the market value of short-term debt is assumed to equal its book value, the market value of long-term debt depends on the age structure of the debt and the change in interest rates over time. I use the method of and Brainard et al. (1980) to estimate the market value of long-term debt.

The value of assets is the sum of the net value of plant and equipment, inventories, accounting intangibles, and investments in unconsolidated subsidiaries adjusted for inflation.

\footnotetext{
10 Specifically, the creators of Regdata use an algorithmic classifier including industries where the classifier has
} an ROC AUC score greater than or equal to 0.75 in 5 -fold cross validation. 
I calculate the replacement value of plant and equipment using the method of the method of Lewellen and Badrinath (1997) using the NIPA investment deflator. ${ }^{11}$ Note that financial firms often do not include plant and equipment on their balance sheets; these firms are excluded from the Tobin's Q regression, but are included in the regressions on operating profits.

The various capital stocks are calculated using the perpetual inventory method with deflators to calculate current value stocks. Following the literature, I assign a depreciation rate and pre-sample growth rate to each series. Robustness checks show that the estimated marginal effects are not sensitive to the particular choice of these rates. The R\&D stock is calculated assuming a $15 \%$ annual depreciation rate and an $8 \%$ pre-sample growth rate (Hall 1990); R\&D expenditures are deflated using an $\mathrm{R} \& \mathrm{D}$ deflator. The advertising stock is based on advertising and marketing expenditures and assumes a $45 \%$ annual depreciation rate and 5\% pre-sample growth rate (Villalonga 2004, p. 217). The "organizational capital” stock is calculated using sales, general, and administrative expenditure (SGA), assuming a 15\% depreciation rate and a $6 \%$ pre-sample growth rate. Note that these expenditures include advertising and marketing spending. They also typically include spending on IT services and most inhouse software development. Both expenditures are deflated using the GDP deflator.

Financial statements do not report R\&D, advertising, or SGA when the quantities are not material to the financial results of the firm. In these cases, the quantities might still be positive, but small. In the regressions, I code missing data for these variables to zero but I include a dummy variable flagging the missing data.

\footnotetext{
11 Thanks to Bronwyn Hall for providing Stata code to compute this. The code was developed by Bronwyn and Daehwan Kim.
} 
The lobbying and campaign expenditure data come from the Center for Responsive Politics. ${ }^{12}$ For each data set, I matched the company name (the client parent entity in the lobbying data, the short name of the political action committee for business PACs in the expenditure data) to Compustat companies. ${ }^{13}$ The lobbying data begin in 1998; the campaign expenditure data are assigned to the election year beginning in 2000 . I assumed a $25 \%$ depreciation rate and a $6 \%$ pre-sample growth rate for each and deflated both using the GDP deflator.

To measure industry concentration, I use data from the US Economic Census for the share of receipts going to the top four firms in each NAICS industry. ${ }^{14}$ I used the Census data for 2002 and 2012, interpolating and extrapolating linearly from 2000 through 2014. In order to measure concentration over the entire sample time frame, I also developed an alternative measure based on the share of 3-digit SIC industry revenues reported in Compustat going to the top three firms in Compustat. ${ }^{15}$

To measure stock volatility, I measure the annual standard deviation in firm daily stock returns reported in the data of the Center for Research in Security Prices (CRSP).

\section{Regulation index}

The final key variable is the index of industry-weighted regulatory constraints developed by Al-Ubaydli and McLaughlin (2015). Prior researchers have measured regulatory complexity using page counts, word counts, or file sizes of the text of the Federal

\footnotetext{
12 Data downloaded from http://www.opensecrets.org/resources/create/data_doc.php.

${ }^{13}$ For the lobbying data, of the 19,359 entities (companies, unions, trade associations, other organizations), $11 \%$ were matched to Compustat firms; these firms accounted for $53 \%$ of all lobbying expenditures. Of the 3,720 PACs, 38\% were matched to Compustat, accounting for $54 \%$ of all expenditures.

${ }^{14}$ In Compustat, firms are assigned to NAICS at different levels of industry detail, from 2-digit to 6-digit. I matched to the concentration ratio for each level of detail. I also used an SIC to NAICS walkway for firms that listed SIC industries, but not NAICS.

15 Details and results available from author.
} 
Register or Code of Federal Regulations (Coglianese 2002; Mulligan \& Shleifer 2005;

Dawson \& Seater 2013; Crews 2011; Coffey et al. 2012). This new index improves on these measures by linking the titles and parts of the code to specific industries. Al-Ubaydli and McLaughlin use an algorithm to probabilistically assign each section of the Code to a specific NAICS industry. They do this assignment for sets of 2-digit, 3-digit, and 4-digit NAICS industries. The result is a time series of the extent of regulation for specific industries since 1970.

For example, Figure 3 shows the series for Title 12, Banks and Banking, weighted for NAICS 522, Credit Intermediation and Related Activities. This figure clearly shows deregulation during the 1980s and later jumps in the extent of regulation in 1991 and 2010 and after. These latter increases were associated with Truth in Lending regulations following the Fair Credit and Charge Card Disclosure Act of 1988, the Home Equity Loan Consumer Protection Act of 1988, and the Higher Education Opportunity Act of 2008. Further large increases after 2010 are associated with the Dodd-Frank Wall Street Reform and Consumer Protection Act.

While this regulation index is not a capital stock per se, it can be incorporated into equations (3) and (4) in a way parallel to the capital stocks above. An intangible capital stock generates rents in proportion to the size of the stock. To the extent that regulations create market power, the absolute measure of rents generated should be proportional to firm revenues, all else equal. That is, an oligopoly markup of prices over cost would benefit all firms in an industry in proportion to their revenues. ${ }^{16} \mathrm{I}$ thus measure the rent-generating potential of regulation for a firm as the regulation index for a given year times firm revenues.

\footnotetext{
${ }^{16}$ Some rents might take the form of lump sum distributions. Comparing a specification of this form (not scaled), the explanatory power of the scaled specification is superior.
} 
I use 3-digit NAICS weighted word counts from Regdata version 2.2. The 3-digit data provide coverage for most of the Compustat sample (69\%).

\section{Summary statistics}

Sample means, weighted by net capital in order to represent aggregate ratios, are shown in Table 1 at three different dates. Tobin's Q increased sharply from 1970 to 2000 and declined modestly since then. A similar pattern is seen in the R\&D and advertising stocks. The SGA stock shows a secular decline while the regulation stock shows a large secular increase. Since 2000, industry concentration and lobbying stocks have increased; campaign spending has increased dramatically. However, both lobbying and election spending quantities are quite small compared to the other stocks measured. Finally, the regulation index shows strong growth, increasing nearly six-fold since 1970.

\section{Accounting for firm profits}

\section{Accounting for Tobin's $Q$}

Table 2 shows estimates of equation (3). I estimate the equation using Non-linear Least Squares with robust standard errors clustered by major industry group. ${ }^{17}$ All regressions include year dummies, as per equation (3) that are not reported. For observations missing data in the R\&D, advertising, and SGA variables, I coded the variable to zero and included a dummy variable to flag the missing data.

The first column uses only the stocks of intangible assets. These all have highly significant coefficients. The bottom panel of the table shows the extent to which the

${ }^{17}$ Using firm SIC codes, I classified firms into major industry groups according to the 9 major divisions of the SIC hierarchy with two additional groups for chemicals and pharma (SIC 28) and for tech (SIC 357, 367, and 737). 
coefficients can account for the change in $\log$ Q. I take the difference between the sample mean of the independent variable between the end and beginning of the sample period. These means are weighted by net capital in order to capture the impact on aggregate log Q. I multiply the difference in means by 100 times the coefficient to present the impact in percentages. As can be seen, growth in intangibles "explain" about one sixth of the rise in Tobin's Q from 1970 to 2014. R\&D and advertising had a positive impact, but SGA had a negative impact.

Column 2 adds the regulation variable. The coefficient is significant and the implied impact on $\log \mathrm{Q}$ is substantial. Combined, the regression variables account for nearly half of the rise in Tobin's Q.

Column 3 adds the volatility of the firm's common stock and the measure of industry concentration derived from Compustat data. Volatility tends to reduce firm value while industry concentration increases it. But neither effect is large and the industry concentration coefficient is not statistically significant. This suggests that the substantial association between regulation and firm value is not explained by these measures of industry concentration. It could be that this concentration measure does not pick up the relevant effect of market power, for example, the relevant market might be much narrower than the 3-digit industry classification.

The regulation variable is an industry specific measure; most of the variation in industry restrictions is cross-sectional rather than time based. It is possible that the coefficient on the regulation variable might reflect some other industry specific variable that is omitted from the regression. To control for omitted industry specific effects, column 4 adds dummy variables for major industry group. Compared with column 2 , the dummy variables improve the R-squared modestly and decrease the coefficient on regulation 
modestly, leaving it statistically significant only at the $10 \%$ level $(\mathrm{P}=.054)$. But the overall impression is that the regulation coefficient does not seem to be mainly reflecting some omitted industry specific variable. I will test this further below with a difference-indifferences specification.

Finally, column 5 adds the industry concentration ratio from the Economic Census and also stocks for lobbying and campaign expenditures. Because these data are only available for more recent years, this regression only covers from year 2000 through 2014. As in column 3, the industry concentration measure is positive but neither economically nor statistically significant.

The lobbying coefficient is highly significant while the campaign-spending coefficient is statistically significant at the $5 \%$ level. The coefficients on both are much larger than one, suggesting that these investments appear to generate much larger returns than investments in plant and equipment. The high level of returns has been noted in the literature (Alexander, Mazza, and Scholz 2009; Cooper, Gulen, and Ovtchinnikov 2010; Hill et al. 2013; Chen, Parsley, and Yang 2015). ${ }^{18}$ Hill et al. (2013, p. 955) propose that various frictions might constrain the extent to which firms lobby so that they cannot increase spending until the marginal benefit equals the marginal cost. Another explanation is that lobbying and campaign spending comprise only a small part of firms' investments in rent seeking. These variables serve as proxies for much more extensive investments and, so, their coefficients are inflated. This interpretation is supported by the large role played by the regulation variable,

\footnotetext{
18 A case study by Alexander, Mazza, and Scholz (2009) found that one dollar in lobbying expense returned $\$ 220$ in tax savings. Cooper, Gulen, and Ovtchinnikov (2010) report that "in our sample, firms invest an average total contribution amount per year of $\$ 23,471$ and earn an average increase in shareholder wealth of \$163.8M per year."
} 
which might reflect other rent seeking investments. The impact of regulation is larger than the impact of the other political variables combined.

Overall, the relative contributions of the different variables to the change in Tobin's Q changed after 2000. The variables representing intangible investments tended to decline while the political variables increased.

\section{Accounting for operation margins}

Table 3 shows four similar regressions on operating margins (operating income after depreciation before interest and taxes divided by net revenues). These are estimated using weighted least squares where the weights are deflated sales so that the results reflect aggregate profit margins. Here the independent variables are beginning-of-year stocks (that is, lagged stocks) divided by sales. As before, missing data on intangibles are coded to zero. ${ }^{19}$ The right hand variables include $\mathrm{R} \& \mathrm{D}$, advertising, SGA, lobbying, and election campaigns. I also include the regulation index and the net capital stock divided by sales, in order to capture returns on tangible capital as well. The bottom panel of shows the effect on the change in operating margins for each independent variable calculated at the sample means as in Table 2.

The first two columns in the top panel cover the entire period (less the first year, dropped for lagged variables). The first column excludes political variables and, as in the previous table, these account for about one sixth of the growth in operating margins. Column two adds the regulation index. Both intangibles and regulation have statistically significant and economically substantial effects on operating margins, especially regulation.

\footnotetext{
${ }^{19}$ Because operating profit is calculated by subtracting expenditures from revenues, I use lagged variables because any measurement error will spuriously cause a negative correlation. In addition some time lag naturally arises before many of these investments pay off.
} 
Regulation accounts for over half of the increase in operating margins. The third column includes the political variables. Because campaign spending is assigned to election years, this regression covers only odd years from 2001 through 2013. Campaign spending has a large and statistically significant impact. During this period, however, the contribution of intangibles was negative because spending declined in these categories. In contrast, spending increased on political activities and the regulation index also grew.

The bottom panel takes a deeper look into regulation; it repeats the regression in column two, but breaks out the regulation index into component indices for the top ten titles in the CFR plus a category for the remaining titles. The top ten titles account for $73 \%$ of the regulation words across the entire sample and most of the variation in the composite index. This regression also adds major industry dummy variables and clusters errors by major industry. The regulation coefficients are jointly highly significant and can more than "explain" the growth in operating margins. But clearly there is substantial heterogeneity across regulatory areas. Banking, the tax code, environmental regulation, and the remainder category all have substantial positive effects on firm profits on average; aerospace and Federal contracting regulations have a negative effect.

In summary, the growth of intangibles and the growth of regulation and political rent seeking activities are substantially associated with the rise in corporate valuations and operating profits. However, since 2000, investments in intangibles have declined relative to tangible capital while regulation and election spending have continued to increase. Thus political variables "explain" much of the rise in profits and corporate valuations since 2000. Finally, the rents generated by regulation appear to be concentrated in a few areas of regulation and, hence, in a few industries, most notably banking, securities, and chemical manufacture, including pharmaceuticals. 


\section{Causality Tests}

However, this is only an accounting exercise. While greater regulation is associated with higher profits and valuations, this exercise does not necessarily imply that greater regulation caused the rise in profits and valuations. In fact, there might be good reasons why the causality could flow from higher profits to greater regulation. In the public interest account, regulation aims to correct market failures. Sustained corporate market power might be an indication of a market failure, providing a target for regulators. Historically, for example, large profits by monopolists encouraged "trust-busting” by Progressive reformers.

Also, both profits and regulation might grow in response to some third factor. For example, major new technologies could bring profits and existing industries might seek new regulation to limit the effects of new technology. In this case it would be a mistake to assume that the regulatory rent seeking caused the profits.

This section performs several tests of the causal link between regulation and corporate valuations and profits.

\section{Granger causality}

Granger causality (1969) provides a baseline test. This procedure tests whether lagged values of an independent variable have explanatory power beyond the lagged values of the dependent variable. Because the linear form of equation (4) lends itself to the analysis, I examine the causality regarding operating margins. ${ }^{20}$

Table 4 shows these regressions for the composite regulation index (top panel) and tests for the joint significance of the relevant coefficients in the bottom panel for both the composite index and separately for major title of the CFR.

\footnotetext{
${ }^{20}$ In addition, Tobin's Q analysis excludes financial firms, an important sector for this analysis.
} 
The table shows that profits do not Granger-causes regulation, except for Title 21, Food and Drug regulations. But regulation does Granger-cause operating margins, although not with high significance for the non-enumerated titles.

This finding is sufficient to reject the simple reverse causality story; if high profits caused regulators to act, then regulation would reflect lagged profits. However, Granger causality does not mean that regulation causes increased profits in the normal sense of causation. For instance, both profits and regulation might be caused by some third factor, yet regulation might respond more rapidly than profits, so that regulation would have explanatory power before profits. Such an explanation is possible, but the slow nature of regulatory change makes this sort of explanation seem unlikely. As noted, the regulatory approval process has built-in delays. In contrast, firms are generally assumed to respond quickly to profit opportunities. If some third factor is driving both new regulations and corporate profits, it seems hard to see how typically slow regulators would be able to respond several years before firms do.

\section{Major regulatory changes}

This Granger analysis considers all regulatory changes affecting the sample industries over three decades. Most regulatory changes are relatively small. It is possible, however, that firms and political actors behave differently when major regulatory changes are at stake.

This might be the case, for instance, if public advocacy faces a collective action problem (Olson 1965). Those industries most affected by regulations will have the greatest incentive to invest in rent seeking, tending to dominate the ordinary process of regulation, all else equal. Other interests that are less directly affected have greater difficulty organizing collective action because the individual rewards are lower. Occasionally, however, broad 
coalitions of opposing interests may be motivated to act, they may overcome their collective action problem, and when they do, one might expect major regulatory changes to follow.

If this view is correct, then major regulatory changes might be relatively more affected by public interests that act in response to corporate market power. It might be the case that major regulatory changes are influenced by prior corporate profits even if that is not the case in general as suggested by the Granger analysis above.

To consider this possibility, I conducted a Probit analysis of the factors associated with major changes in regulation, including lagged operating margins. I then conducted a difference-in-differences analysis to see if these large changes in regulation in select industries led to profit increases relative to a control group. I began by identifying the industries most affected by major changes for each of the top ten Titles of the CFR. I identified the 3-digit NAICS industry that had the highest number of weighted words for each Title. For example, NAICS 522, Credit Intermediation and Related Activities, was the industry most affected by Title 12, Banks and Banking. The full list of affected industries can be seen in Table A1 in the Appendix.

Next I needed to choose those years where the weighted number of words for each Title:industry pair increased substantially; these are presumably the events where the impact of regulatory change should be most visible. ${ }^{21}$ I needed to choose a threshold so that an industry might have a few events during the sample period, but not so many that the effect of one event tended to overlap other events. ${ }^{22}$ To do this, I first used a threshold of 100,000 for the year-to-year difference in weighted words, excluding cases where a similar event

\footnotetext{
${ }^{21}$ I study decreases in a separate paper on deregulation.

${ }^{22}$ I tested a variety of alternative thresholds. While some created problems with overlapping events, the estimates I obtain below appeared robust to these choices.
} 
occurred during the prior three years; this yielded seventeen events in six Titles. Then I repeated the process for the four remaining Titles, using a threshold of 50,000. This left a total of 24 events, covering all ten Titles (see Table A1).

Finally, I explored the regulatory history of each change to understand the nature of the changes. ${ }^{23}$ Some of the changes were not substantive changes in regulation; for example, the FDA recodified Title 21 in 1974, leading to changes in word counts, but not real change in the law. Other major changes were not primarily relevant to the selected industry; in particular, we could not identify the industry-specific sections for changes in the income tax code (Title 26, Part 1). For these two reasons, I designated a sub-sample where documentary evidence suggests that the change in regulation was substantive and it affected the designated industry.

The first question to address with this dataset of major regulatory changes is whether firm operating margins tend to increase the probability of a major regulatory change. Table 5 shows Probit regressions on the occurrence of a major regulatory change. The sample consists of all firm-year observations from the industries that experience major changes. ${ }^{24}$ All regressions include year dummies and dummies for major industry groups. The first two columns include all events, the last two columns, only those events that are judged substantive to the affected industry. The coefficient for Log employment is statistically significant and the industry dummy variables are jointly significant, but coefficients for lagged operating margins are neither individually nor jointly statistically significant. In

\footnotetext{
23 Thanks to Stefanie Weigmann for much of this analysis. See Table A1 for summaries.

${ }^{24}$ Other industries are not paired with the top ten Titles and are thus excluded from the assignment of major changes.
} 
summary, these tests reject the hypothesis that high profits are responsible for subsequent major increases in regulation.

\section{Difference-in-differences}

In order to consider other possible causal interactions, I used these events of major increases in regulation to conduct a difference-in-differences analysis. Under the assumption that the control and treatment groups share a common underlying trend aside from the treatment, a difference-in-difference analysis compares the difference between the treatment and control groups before and after the event. A simple way to estimate these differences is with a regression of the form

$$
\text { (5) } \left.\left.y_{i}=\alpha \cdot I \text { (treatment group) }+\beta \cdot I \text { (post event }\right)+\gamma \cdot I \text { (treatment \& post }\right)+\varepsilon_{i} \text {, }
$$

where $y_{i}$ is the dependent variable and $I$ is an indicator function designating a dummy variable. The coefficient $\gamma$ is the measure of the average treatment effect on the treated, the difference-in-differences (DID).

For each firm in an industry affected by a major change, I constructed a panel consisting of the three years prior to the change and three years after. ${ }^{25}$ These firms constituted the treatment group. I constructed a basic control group by selecting firms in industries that did not experience major regulatory change (a change of more than 10,000 words in either direction) during the year of the treatment event or during the preceding three years or the following three years.

Table 6, column 1 shows the analysis for the entire sample of panels pooled for all events, using operating margins as the dependent variable. During the pre-event period, treatment firms had operating margins that were about $2 \%$ lower than the control group;

\footnotetext{
${ }^{25}$ Keeping only those panels that had data for the third year before and after.
} 
after the event, treatment firms averaged operating margins were $4 \%$ higher, leaving a difference-in-differences of about a $6 \%$ increase in profits. Because of concerns about serial correlation (Bertrand, Duflo, and Mullainathan 2004), the standard errors are block bootstrapped by firm using 200 repetitions. This increase is statistically significant.

The critical assumption is that the treatment and control groups follow the same trend between the pre- and post-periods so that in the counterfactual case without treatment, the difference in differences would be zero. While this assumption cannot be directly tested, it can be thrown into doubt if the treatment and control groups exhibit different trends before the event. I estimated the trend as the change between three years before the event and the year before. The difference in the pre-event trend was large (.14), although not statistically significant.

Column 2 repeats these calculations but only for those events judged to be substantive. Now profits increased by $8 \%$ in the treatment group relative to the control group; the pre-event trend difference was also smaller. Column 3 uses a different control group, namely all Compustat firms. These results are similar to column 2.

Column 4 uses the original control group but adds controls for tangible and intangible assets. I do this by regressing operating income on these variable (and time dummies) as in Table 3, Column 1, and using the residuals from this regression as the dependent variable in the DID analysis. The residual is effectively a measure of excess profits. Now treatment group profits increase about $6 \%$ relative to the control group and the pre-event trend difference is negligible. Finally, column 5 does the same analysis, but weights the observations with a kernel-based propensity score (Heckman et al. 1998); that score is 
based on a Probit regression using log employment and industry dummy variables as in Table $5{ }^{26}$ These results are close to those in column 4 .

This table presents the results for pooled panels. Table A1 in the Appendix shows results for separate events, using residuals for the dependent variable. Of the 15 substantive changes, 12 have positive coefficients. However, the role of Title 12 and the banking industry seems particularly strong. Repeating the regression in column 4 but excluding Title 12 , the DID estimate is smaller at 3.8\%, but still highly significant (standard error of $1.3 \%$ ). One might also be concerned about the effect of the recent recession. Excluding events after 2008, the DID estimate is $4.1 \%$ (standard error of $1.3 \%$ ).

In summary, firms in industries experiencing a major increase in regulation saw significantly increased profits relative to control groups and this finding seems robust to several considerations.

\section{Discussion}

\section{What does regulation do?}

The empirical findings suggest that increases in the complexity of regulation are causally associated with increased firm profits in the affected industries. These results are difficult to reconcile with the idea that firm profits induce greater regulation. They are also difficult to reconcile with the hypothesis that a third factor such as technology increases both regulatory complexity and firm profits — the timing for this story requires that the impact of the technological or other change occurs in exactly the year that the final rule is issued, yet

${ }^{26}$ I use the Stata diff routine developed by Villa (2012). 
new regulation is usually years in the making, often involving new legislation, multiple proposed rules, and, sometimes, legal challenges (see Table A1).

This analysis does not, however, explain how the profits associated with regulation are created. The possibilities include government grants of exclusive assets such as wireless spectrum or oil leases, the creation of entry barriers, either explicit (patents) or as an indirect of costly regulation, regulatory rate setting, and government contracts, tax breaks, subsidies, and bailouts. Some insight can be gained by looking at a case study.

Crawford (2000) analyzes one of the events included in the difference-in-differences analysis. In response to concerns that excessive cable television prices reflected monopoly rents, Congress passed the Cable Television Consumer Protection and Competition Act of 1992 "to provide increased consumer protection." The FCC promulgated extensive new regulations the next year. Given this background, one might expect that these regulations reduced cable TV profits. Indeed, this is what regulators supposed; the Federal Communications Commission estimated that cable prices would fall $10 \%$, saving households over $\$ 1$ billion (FCC 1993). As such, this account seems to correspond to the public interest view that regulators respond to needs of the public; it also corresponds to the tollbooth view in so far as regulators took actions that might extract rents from firms (McChesney 1987; Djankov et al. 2002).

However, households did not benefit from the new regulation overall. Crawford (2000) shows that the actual realized prices did not fall and about one third of households actually paid more. ${ }^{27}$ How did this happen? The complex regulations provided cable companies with substantial latitude to evade the price decreases by changing programming

\footnotetext{
${ }^{27}$ In the difference-in-differences analysis, the profit residuals increased relative to the control group, but the increase is not statistically significant (see Appendix Table A1).
} 
mix and quality. The cable companies did reduce fees on their basic packages, but they also cut the programming provided in those packages, shifting desired programs to more costly bundles. In addition to influencing the details of this legislation and regulation, the cable companies engaged in substantial market-based rent seeking activity by changing their offerings.

Thus the complexity of regulation appears to have created the opportunity for firms to earn greater rents despite the consumerist, anti-competitive intent of the legislation. This might seem consistent with Stigler's (1971) theory of regulation that "as a rule, regulation is acquired by the industry and is designed and operated primarily for its benefit." However, this example does not seem to be an instance of captured regulators; the regulators aimed to lower cable prices, contrary to what the industry wanted, and they expected the regulation to reduce firm profits. ${ }^{28}$ Instead, the mechanism seems to be a sort of systemic capture facilitated by regulatory complexity (McCarty 2013, Drutman 2015).

\section{Regulation and rent seeking}

While the difference-in-differences analysis implies that more extensive regulation increases firm profits, it also does not explain what causes the increase in regulation. Corporate political activity such as lobbying might cause the increase, but that is not necessarily so. For instance, regulation might increase because technologies are getting more complicated. For example, new automotive safety technology appeared to provide a reason for increases in the size of transportation regulation in Title 49. On the other hand, lobbying

${ }^{28}$ Indeed, in response to an earlier account of this research, one of the 1993 FCC Commissioners posted an online comment consistent with the record that "Our agency was not captured. Indeed, the industry vilified me” Marginal Revolution, 6/15/2016, http:/ /marginalrevolution.com/marginalrevolution/2016/06/regulationand-rents.html. 
might also play a role in the development of these complex new regulations-lobbying and political spending are correlated with regulation. ${ }^{29}$ Given that greater regulation appears responsible for a sizeable part of the increase in firm profits, it would be puzzling if firms did not lobby or pursue other forms of rent seeking when faced with new regulation. ${ }^{30}$ Thus, while regulation helps profits, the link between regulation and corporate political activity appears complicated.

\section{Conclusion}

Much of the growth in corporate valuations and profits since 1980 can be accounted for by growing investments in intangibles, especially investment in R\&D. But it appears that an even larger share of the rise in valuations and profits can be accounted for by factors associated with growing regulation and political activity, especially after 2000. Moreover, this relationship appears causal: increases in regulatory complexity appear to cause subsequent increases in profits.

And these benefits appear to be large. Regulation corresponds to an increase in corporate valuations of about $\$ 2$ trillion in the sample (Table 2, Column 2). Regulation and campaign spending are responsible for an increase in markups on the order of 1-2 percent (Table 3, Column 2). That corresponds to about a $\$ 400$ billion increase in transfers from consumers to firms each year.

Several qualifications affect the interpretation of these findings. First, regulatory rents are not substantial in most industries; they are highly concentrated in a small number

\footnotetext{
${ }^{29}$ Aggregating lobbying and campaign expenditures across 3-digit NAICS industries, the correlations with the total number of regulatory words weighted by industry relevance have coefficients of 0.63 and 0.33 respectively.

${ }^{30}$ For instance, the regulation index is also correlated with the share of lawyers in an industry's workforce (correlation coefficient of 0.44 excluding legal firms).
} 
of industries. This has implications for the dispersion of firm profits that might be related to rising inter-firm wage inequality.

Second, this study only looks at publicly listed firms. The effect of regulation might be quite different on private firms, especially small firms. Indeed, if rents are created via barriers to entry, one might expect large firms to benefit and small firms to be harmed.

This raises an additional limitation. While this study finds a large, causal effect from regulation, it does not identify the actual mechanism at work. Nor does it identify the exact role of corporate political activity. These are important for understanding the implications of the rise in regulatory rents, their normative significance, and possible policy responses.

Despite these limitations, the findings highlight the importance of looking at the link between regulation and rents broadly:

- Some observers have highlighted the possible role of increasing industry concentration in generating economic rents (Grullon, Larkin, and Michaely 2015, CEA 2016). Using two different measures of concentration, I find only a weak relationship with profits that is neither statistically nor economically significant. Regulation may be more important than industry concentration in generating rents and, for that reason, market power may be more than a matter for antitrust policy alone.

- Compliance costs of regulation might be beneficial to some firms. Despite possibly substantial compliance costs (Crews 2011), complex regulation is associated with greater profits among public firms, perhaps because compliance costs create entry barriers.

- As in the cable TV example, regulatory complexity can generate rents even when individual regulators are not "captured” or even "culturally captured” (Kwak 2013). While the corruption or biasing of individual regulators is surely important, the role of 
complexity highlights the importance of a systemic notion of capture (McCarty 2013,

Drutman 2015).

- While I have linked regulatory complexity to firm profits, the link between corporate political activity and regulatory complexity is unclear and might well involve multiple paths of causation. Moreover, corporate rent-seeking likely involves much more than lobbying and campaign contributions.

Thus although regulation appears central to understanding the link between politics and corporate rents, many questions remain unanswered.

\section{References}

Al-Ubaydli, O. and McLaughlin, P.A., 2015. RegData: A numerical database on industryspecific regulations for all United States industries and federal regulations, 19972012. Regulation \& Governance.

Alexander, R., Mazza, S.W. and Scholz, S., 2009. Measuring rates of return for lobbying expenditures: an empirical analysis under the American Jobs Creation Act. Journal of Law and Politics, 25(4), pp.401-457.

Angrist, J., 1998. Estimating the Labor Market Impact of Voluntary Military Service Using Social Security Data on Military Applicants. Econometrica,66(2), pp.249-288.

Ansolabehere, S., de Figueiredo, J.M. and Snyder, J.M., 2003. Why Is There so Little Money in US Politics?. The Journal of Economic Perspectives, 17(1), pp.105-130.

Bailey, J. and D. Thomas, 2015. Regulating Away Competition: The Effect of Regulation on Entrepreneurship and Employment, Mercatus Working Paper, George Mason University.

Bertrand, M., Duflo, E. and Mullainathan, S., 2004. How Much Should We Trust Differences-in-Differences Estimates? Quarterly Journal of Economics, 119(1).

Bessen, J., 2009. Estimates of patent rents from firm market value. Research Policy, 38(10), pp.1604-1616.

Bonardi, J.P., Holburn, G.L. and Bergh, R.G.V., 2006. Nonmarket strategy performance: evidence from US electric utilities. Academy of Management Journal, 49(6), pp.12091228.

Borisov, A., Goldman, E. and Gupta, N., 2015. The corporate value of (corrupt) lobbying. Review of Financial Studies, p.hhv048. 
Brainard, W.C., Shoven, J.B., Weiss, L., Cagan, P. and Hall, R.E., 1980. The financial valuation of the return to capital. Brookings Papers on Economic Activity, 1980(2), pp.453-511.

Chen, H., Parsley, D. and Yang, Y.W., 2015. Corporate lobbying and firm performance. Journal of Business Finance \& Accounting, 42(3-4), pp.444-481.

Cockburn, I. and Griliches, Z., 1988. The estimation and measurement of spillover effects of $\mathrm{R} \& \mathrm{D}$ investment-industry effects and appropriability measures in the stock market's valuation of R\&D and patents. The American Economic Review, 78(2), pp.419-423.

Coffey, B., McLaughlin, P.A. and Tollison, R.D., 2012. Regulators and Redskins. Public Choice, 153(1-2), pp.191-204.

Coglianese, C., 2002. Empirical analysis and administrative law. U. Ill. L. Rev., p.1111.

Cooper, M.J., Gulen, H. and Ovtchinnikov, A.V., 2010. Corporate political contributions and stock returns. The Journal of Finance, 65(2), pp.687-724.

Council of Economic Advisers, April 2016. Benefits of Competition and Indicators of Market Power, Issue Brief.

Crawford, G.S., 2000. The Impact of the 1992 Cable Act on Household Demand and Welfare, RAND Journal of Economics, 31, p.422.

Crews CW (2011) Ten Thousand Commandments: An Annual Snapshot of the Federal Regulatory State. Competitive Enterprise Institute, Washington, DC.

Dasgupta, P. and Stiglitz, J., 1980. Industrial structure and the nature of innovative activity. The Economic Journal, 90(358), pp.266-293.

Dawson, J.W. and Seater, J.J., 2013. Federal regulation and aggregate economic growth. Journal of Economic Growth, 18(2), pp.137-177.

Dean, T.J. and Brown, R.L., 1995. Pollution regulation as a barrier to new firm entry: Initial evidence and implications for future research. Academy of Management Journal, 38(1), pp. 288-303.

de Figueiredo, John M. and Brian Kelleher Richter. 2014. “Advancing the Empirical Research on Lobbying.” Annual Review of Political Science. 17:163-85.

Djankov, S., La Porta, R., Lopez-de-Silanes, F. and Shleifer, A., 2002. The regulation of entry. Quarterly journal of Economics, pp.1-37.

Drutman, L., 2015. The business of America is lobbying: How corporations became politicized and politics became more corporate. Oxford University Press.

Duchin, R. and Sosyura, D., 2012. The politics of government investment. Journal of Financial Economics, 106(1), pp.24-48.

Dunne, T., Foster, L., Haltiwanger, J. and Troske, K.R., 2004. Wage and Productivity Dispersion in United States Manufacturing: The Role of Computer Investment. Journal of Labor Economics, 22(2), pp.397-430.

Eisfeldt, A.L. and Papanikolaou, D., 2013. Organization capital and the cross-section of expected returns. The Journal of Finance, 68(4), pp.1365-1406.

Federal Communications Commission (FCC). Changes in Cable Television Rates: Results of the FCC's Survey of September 1, 1993 Rate Changes, (2nd Cable Price Survey), FCC Mass Media Docket No. 92-226, Washington, D.C., February 22, 1994. 
Fullerton, D. and Lyon, A.B., 1988. Tax neutrality and intangible capital. InTax Policy and the Economy: Volume 2 (pp. 63-88). MIT Press.

Furman, J. and Orszag, P., 2015. A Firm-Level Perspective on the Role of Rents in the Rise in Inequality. Presentation at "A Just Society" Centennial Event in Honor of Joseph Stiglitz Columbia University.

Goldman, E., Rocholl, J. and So, J., 2013. Politically connected boards of directors and the allocation of procurement contracts. Review of Finance, p.rfs039.

Goldschlag, N. and Tabarrok, A.T., 2014. Is Regulation to Blame for the Decline in American Entrepreneurship?. Available at SSRN 2559803.

Granger, C.W., 1969. Investigating causal relations by econometric models and crossspectral methods. Econometrica: Journal of the Econometric Society, pp.424-438.

Griliches, Z., 1981. Market value, R\&D, and patents. Economics letters, 7(2), pp.183-187.

Grullon, G., Larkin, Y. and Michaely, R., 2015. Are US Industries Becoming More Concentrated? Working Paper.

Hadani, Michael, and Douglas A. Schuler. "In search of El Dorado: The elusive financial returns on corporate political investments." Strategic Management Journal 34.2 (2013): 165-181.

Hall, B.H., Mansfield, E. and Jaffe, A.B., 1993. Industrial research during the 1980s: Did the rate of return fall?. Brookings Papers on Economic Activity. Microeconomics, 1993(2), pp.289-343.

Hall, B.H., Berndt, E. and Levin, R.C., 1990. The Impact of Corporate Restructuring on Industrial Research and Development. Brookings Papers on Economic Activity. Microeconomics, 1990, pp.85-135.

Hall, B.H., Jaffe, A. and Trajtenberg, M., 2005. Market value and patent citations. RAND Journal of Economics, pp.16-38.

Hayashi, F., 1982. Tobin's marginal q and average q: A neoclassical interpretation. Econometrica: Journal of the Econometric Society, pp.213-224.

Hayashi, F. and Inoue, T., 1991. The Relation Between Firm Growth and Q with Multiple Capital Goods: Theory and Evidence from Panel Data on Japanese Firms. Econometrica: Journal of the Econometric Society, pp.731-753.

Heckman, J., Ichimura, H., Todd, P. "Matching As an Econometric Evaluation Estimator". The Review of Economic Studies, Vol. 65, No. 2 (Apr., 1998), pp. 261-294.

Hill, M.D., Kelly, G.W., Lockhart, G.B. and Ness, R.A., 2013. Determinants and effects of corporate lobbying. Financial Management, 42(4), pp.931-957.

Hochberg, Yael V., Paola Sapienza, and Annette Vissing-Jørgensen. "A Lobbying Approach to Evaluating the Sarbanes-Oxley Act of 2002." Journal of Accounting Research 47.2 (2009): 519-583.

Kearl, J.R., 1983. Rules, rule intermediaries and the complexity and stability of regulation. Journal of Public Economics, 22(2), pp.215-226.

Krueger, A.O. and Duncan, R., 1993. The political economy of controls: Complexity (No. w4351). National Bureau of Economic Research. 
Kwak, James, 2013. "Cultural capture and the financial crisis." in Preventing Regulatory Capture: Special Interest Influence And How To Limit It, eds. Daniel Carpenter, Steven Croley, and David Moss. Cambridge University Press: 71-98.

Lev, B. and Radhakrishnan, S., 2005. The valuation of organization capital. In Measuring capital in the new economy (pp. 73-110). University of Chicago Press.

Lev, B. and Sougiannis, T., 1996. The capitalization, amortization, and value-relevance of R\&D. Journal Of Accounting And Economics, 21(1), pp.107-138.

Lewellen, W.G. and Badrinath, S.G., 1997. On the measurement of Tobin's q. Journal Of Financial Economics, 44(1), pp.77-122.

Loury, G.C., 1979. Market structure and innovation. The Quarterly Journal Of Economics, pp.395-410.

Mayda, A., R. Ludema and P. Mishra (2010), 'Protection for Free? The Political Economy of US Tariff Suspensions', IMF Working Paper 10/211.

McCarty, Nolan, 2013. "Complexity, Capacity, and Capture" in Preventing Regulatory Capture: Special Interest Influence And How To Limit It eds. Daniel Carpenter, Steven Croley, and David Moss. Cambridge University Press.

McChesney, F.S., 1987. Rent extraction and rent creation in the economic theory of regulation. The Journal of Legal Studies, 16(1), pp.101-118.

Mulligan, C.B. and Shleifer, A., 2005. The Extent of the Market and the Supply of Regulation. The Quarterly Journal of Economics, pp.1445-1473.

Murphy, K.M., Shleifer, A. and Vishny, R.W., 1991. The Allocation of Talent: Implications for Growth. The Quarterly Journal of Economics, 106(2), pp.503-530.

Nitzan, S., Procaccia, U. and Tzur, J., 2013. On the Political Economy of Complexity. Working paper.

Olson M. The Logic Of Collective Action Cambridge. Mass.: Harvard. 1965.

Olson, M., 1982. The Rise And Decline Of Nations: Economic Growth, Staflation, And Economic Rigidities. Yale University Press.

Peltzman, S., Levine, M.E. and Noll, R.G., 1989. The economic theory of regulation after a decade of deregulation. Brookings Papers On Economic Activity. Microeconomics, 1989, pp.1-59.

Pigou, A.C., 1920. The Economics of Welfare, 4th. London: Macmillan.

Piketty, T., 2014. Capital in the twenty-first century. Harvard University Press.

Posner, R.A., 1975. The Social Costs of Monopoly and Regulation. The Journal of Political Economy, 83(4), pp.807-828.

Quandt, R.E., 1983. Complexity in regulation. Journal of Public Economics,22(2), pp.199-214.

Richter, B.K., Samphantharak, K. and Timmons, J.F., 2009. Lobbying and taxes. American Journal of Political Science, 53(4), pp.893-909.

Salinger, M.A., 1984. Tobin's q, unionization, and the concentration-profits relationship. the Rand Journal of Economics, 15(2), pp.159-170.

Song, J., Price, D.J., Guvenen, F., Bloom, N. and von Wachter, T., 2015. Firming up inequality (No. w21199). National Bureau of Economic Research.

Stigler, G.J., 1971. The theory of economic regulation. The Bell Journal Of Economics And Management Science, pp.3-21. 
Stiglitz, J., 2012. The Price Of Inequality. Norton.

Tullock, G., 1967. The welfare costs of tariffs, monopolies, and theft. Economic Inquiry, 5(3), pp.224-232.

Villa, Juan M., 2012. Simplifying the estimation of difference in differences treatment effects with Stata. Working paper.

Villalonga, B., 2004. Intangible resources, Tobin's q, and sustainability of performance differences. Journal of Economic Behavior \& Organization,54(2), pp.205-230.

Werner, Timothy, and John J. Coleman. "Citizens United, independent expenditures, and agency costs: Reexamining the political economy of state antitakeover statutes." Journal of Law, Economics, and Organization 31.1 (2015): 127-159.

Werner, Timothy and Brian Roberts 2015. Political Uncertainty and the Returns to Corporate Lobbying," working paper.

Yu, Frank, and Xiaoyun Yu. "Corporate lobbying and fraud detection." Journal of Financial and Quantitative Analysis 46.06 (2012): 1865-1891. 


\section{Tables and Figures}

Table 1. Summary Statistics

Variable

\begin{tabular}{ccc}
\multicolumn{3}{c}{ Mean } \\
1970 & 2000 & 2014 \\
\hline 0.140 & 0.460 & 0.344 \\
0.360 & 1.330 & 2.135 \\
0.060 & 0.116 & 0.108 \\
0.004 & 0.018 & 0.014 \\
0.742 & 0.628 & 0.615 \\
0.021 & 0.031 & 0.014 \\
& 0.429 & 0.438 \\
& 0.168 & 0.204 \\
1445 & 0.001 & 0.017 \\
& 3776 & 2456
\end{tabular}

Note: sample means weighted by net capital. 
Table 2. Log Tobin's Q Regressions

\begin{tabular}{|c|c|c|c|c|c|}
\hline & 1 & 2 & 3 & 4 & 5 \\
\hline Independent Variables & $1970-2014$ & $1970-2014$ & $1970-2014$ & $1970-2014$ & $2000-2014$ \\
\hline R\&D stock / net capital & $0.738(.129)^{* *}$ & $0.772(.134)^{* *}$ & $0.883(.148)^{* *}$ & $0.735(.120)^{* *}$ & $0.567(.104)^{* *}$ \\
\hline $\begin{array}{l}\text { Advertising stock / net } \\
\text { capital }\end{array}$ & $0.600(.171)^{* *}$ & $0.501(.119)^{* *}$ & $0.471(.100)^{* *}$ & $0.459(.140)^{* *}$ & $0.787(.236)^{* *}$ \\
\hline SGA stock / net capital & $0.085(.015)^{* *}$ & $0.061(.015)^{* *}$ & $0.030(.017)$ & $0.065(.014)^{* *}$ & $0.081(.022)^{* *}$ \\
\hline $\begin{array}{l}\text { Regulation index / net } \\
\text { capital }\end{array}$ & & $0.013(.004)^{* *}$ & $0.015(.004)^{* *}$ & $0.010(.005)$ & $0.013(.004)^{* *}$ \\
\hline $\begin{array}{l}\text { Compustat } 3 \text { firm } \\
\text { concentration ratio }\end{array}$ & & & $0.192(.159)$ & & \\
\hline $\begin{array}{l}\text { Standard deviation, daily } \\
\text { stock returns }\end{array}$ & & & $-2.562(.625)^{* *}$ & & \\
\hline $\begin{array}{l}\text { Four-firm share of } \\
\text { industry receipts }\end{array}$ & & & & & $0.032(.111)$ \\
\hline $\begin{array}{l}\text { Lobbying stock / net } \\
\text { capital }\end{array}$ & & & & & $25.257(5.023)^{* *}$ \\
\hline $\begin{array}{l}\text { Election spending stock / } \\
\text { net capital }\end{array}$ & & & & & $414.34181 .21^{*}$ \\
\hline $\begin{array}{l}\text { Dummies for missing } \\
\text { R\&D, advert., \& SGA }\end{array}$ & $\checkmark$ & $\checkmark$ & $\checkmark$ & $\checkmark$ & $\checkmark$ \\
\hline Industry group dummies & & & & $\checkmark$ & \\
\hline Year dummies & $\checkmark$ & $\checkmark$ & $\checkmark$ & $\checkmark$ & $\checkmark$ \\
\hline No. observations & 133,198 & 133,198 & 103,958 & 133,198 & 46,069 \\
\hline Adjusted R-squared & 0.545 & 0.559 & 0.556 & 0.568 & 0.655 \\
\hline \multicolumn{6}{|l|}{ Percent contribution } \\
\hline $\mathrm{R} \& \mathrm{D}$ stock / net capital & 3.50 & 3.66 & 3.13 & 3.48 & -0.30 \\
\hline $\begin{array}{l}\text { Advertising stock / net } \\
\text { capital }\end{array}$ & 0.60 & 0.50 & 0.56 & 0.46 & -0.27 \\
\hline SGA stock / net capital & -1.08 & -0.78 & -0.65 & -0.83 & 0.02 \\
\hline Regulation index / net capit & & 5.70 & 6.26 & 4.39 & 1.84 \\
\hline $\begin{array}{l}\text { Compustat } 3 \text { firm } \\
\text { concentration ratio }\end{array}$ & & & 0.07 & & \\
\hline $\begin{array}{l}\text { Standard deviation, daily } \\
\text { stock returns }\end{array}$ & & & -1.32 & & \\
\hline $\begin{array}{l}\text { Four-firm share of industry } \\
\text { receipts }\end{array}$ & & & & & 0.03 \\
\hline $\begin{array}{l}\text { Lobbying stock / net } \\
\text { capital }\end{array}$ & & & & & 0.10 \\
\hline $\begin{array}{l}\text { Election spending stock / } \\
\text { net capital }\end{array}$ & & & & & 0.71 \\
\hline Change in $\log \mathrm{Q}$ (percent) & 20.39 & 20.39 & 16.59 & 20.39 & -11.53 \\
\hline
\end{tabular}


Table 3. Operating Profits / Sales

\begin{tabular}{llll} 
A. & $1971-2014$ & $1971-2014$ & $\begin{array}{c}2001-2013, \\
\text { odd years }\end{array}$ \\
\hline R\&D/sales, lagged & $0.066(.006)^{* *}$ & $0.038(.006)^{* *}$ & $0.020(.009)^{*}$ \\
Advertising/sales, lagged & $0.018(.013)$ & $0.009(.007)$ & $0.087(.030)^{* *}$ \\
SGA/sales, lagged & $0.001(.001)$ & $0.001(.000)$ & $0.000(.000)$ \\
Regulation words (mill.) & & $0.012(.001)^{* *}$ & $0.013(.001)^{* *}$ \\
Lobbying/sales, lagged & & & $0.670(2.839)$ \\
PAC spending/sales, lagged & & & $288.38(41.93)^{* *}$ \\
Capital/sales & $0.008(.001)^{* *}$ & $0.008(.001)^{* *}$ & $0.009(.001)^{* *}$ \\
Major industry dummies & & & \\
No. of observations & 135,968 & 135,968 & 29,798 \\
R-squared & 0.178 & 0.194 & 0.255
\end{tabular}

\section{Percent contribution}

\begin{tabular}{|c|c|c|c|}
\hline $\mathrm{R} \& \mathrm{D} /$ sales, lagged & 0.35 & 0.20 & 0.01 \\
\hline Advertising/sales, lagged & 0.02 & 0.01 & -0.02 \\
\hline SGA/sales, lagged & 0.01 & 0.00 & 0.00 \\
\hline Regulation words (mill.) & & 1.79 & 0.72 \\
\hline Lobbying/sales, lagged & & & 0.00 \\
\hline PAC spending/sales, lagged & & & 0.45 \\
\hline Change in operating margin & 2.51 & 2.51 & 2.26 \\
\hline B. & & & Percent contribution \\
\hline $\mathrm{R} \& \mathrm{D} /$ sales, lagged & & $0.042(.054)$ & 0.23 \\
\hline Advertising/sales, lagged & & $0.004(.006)$ & 0.01 \\
\hline SGA/sales, lagged & & $0.000(.000)$ & 0.00 \\
\hline \multicolumn{4}{|l|}{ Regulation by title, (mill.) } \\
\hline Title 7, Agriculture & & $-0.001(.032)$ & 0.01 \\
\hline Title 12, Banking & & $0.199(.015)^{* *}$ & 2.83 \\
\hline Title 14, Aerospace & & $-0.187(.020)^{* *}$ & -0.55 \\
\hline Title 21, Food \& Drug & & $-0.018(.042)$ & 0.01 \\
\hline Title 26, IRS & & $0.083(.010)^{* *}$ & 0.69 \\
\hline Title 29, Labor & & $-0.023(.011)$ & -0.13 \\
\hline Title 40, Environment & & $0.012(.007)$ & 1.00 \\
\hline Title 47, Telecomm. & & $0.013(.016)$ & 0.10 \\
\hline Title 48, Fed. Acquisition & & $-0.166(.028)^{*}$ & -0.47 \\
\hline Title 49, Transportation & & $0.027(.012)$ & 0.22 \\
\hline Other titles & & $0.020(.012)$ & 0.42 \\
\hline Capital/sales & & $0.001(.002)$ & \\
\hline R-squared & & 0.328 & \\
\hline
\end{tabular}

Note: WLS estimations of equation (4), weighted by real revenues and including dummies for missing data and year dummies. Robust standard errors in parentheses in Panel A; errors clustered by industry in B.

$* *=$ significant at $1 \%$ level; $*=$ significant at $5 \%$ level. Sample is all US Compustat firms excluding $1 \%$ tails of operating margin and firms where R\&D $>.5 *$ sales. Percent contribution for variable $x$ is $100 \cdot \beta_{x} \cdot\left(\bar{x}_{1}-\bar{x}_{0}\right)$ where the means are calculated for the beginning (0) and end years (1) weighted by real sales. Panel B repeats column 2 of $\mathrm{A}$, but breaks out separate titles and adds major industry dummy variables. 
Table 4. Granger Causality Regression

\begin{tabular}{rlrl}
$\begin{array}{c}\text { Do profits Granger-cause } \\
\text { regulation? }\end{array}$ & $\begin{array}{c}\text { Does regulation Granger- } \\
\text { cause profits? }\end{array}$ \\
\hline & & \multicolumn{3}{c}{ Operating margin } \\
\hline 0.000 & $(.000)$ & $0.090 \quad(.001)^{* *}$ \\
0.000 & $(.000)$ & $0.000 \quad(.000)$ \\
0.000 & $(.000)$ & 0.001 & $(.000)^{* *}$ \\
& & & \\
1.047 & $(.003)^{* *}$ & 0.078 & $(.014)^{* *}$ \\
0.046 & $(.005)^{* *}$ & -0.017 & $(.021)$ \\
-0.077 & $(.003)^{* *}$ & -0.074 & $(.015)^{* *}$ \\
109,046 & & 108,938 & \\
0.994 & & 0.091 &
\end{tabular}

\begin{tabular}{lrr}
$\begin{array}{l}\text { F-test of joint significance of } \\
\text { coefficients } \\
\text { (P values) }\end{array}$ & $\begin{array}{r}\text { Operating } \\
\text { margin } \\
\text { coefficients }\end{array}$ & $\begin{array}{r}\text { Regulation } \\
\text { coefficients }\end{array}$ \\
\hline Total & 0.895 & 0.000 \\
Title 7, Agriculture & 0.847 & 0.000 \\
Title 12, Banking & 0.368 & 0.000 \\
Title 14, Aerospace & 0.998 & 0.000 \\
Title 21, Food \& Drug & 0.004 & 0.000 \\
Title 26, IRS & 0.489 & 0.000 \\
Title 29, Labor & 0.506 & 0.000 \\
Title 40, Environment & 0.052 & 0.000 \\
Title 47, Telecomm. & 0.838 & 0.000 \\
Title 48, Fed. Acquisition & 0.839 & 0.000 \\
Title 49, Transportation & 0.212 & 0.000 \\
Other titles & 0.860 & 0.073 \\
\hline
\end{tabular}

Note: OLS estimation. Standard errors in parentheses. $*^{*}=$ significant at $1 \%$ level; $*=$ significant at $5 \%$ level. Regressions also include year dummy variables. The top panel reports regressions using the composite regulation index; the bottom panel reports F-test probability values for the joint significance of the relevant coefficients 
Table 5. Probit Regressions of Major Regulatory Increases

\begin{tabular}{lcccc} 
Sample & \multicolumn{2}{c}{ All events } & \multicolumn{2}{c}{ Substantive for industry } \\
& 1 & 2 & 3 & 4 \\
\hline Operating margin & & & & \\
$\quad$ Lag 1. & $0.000(.001)$ & $-0.001(.001)$ & $0.001(.001)$ & $0.002(.001)$ \\
$\quad$ Lag 2. & $0.000(.000)$ & $0.000(.000)$ & $0.000(.000)$ & $0.000(.000)$ \\
$\quad$ Lag 3. & $0.000(.000)$ & $0.000(.000)$ & $0.000(.001)$ & $0.000(.001)$ \\
Capital / sales & & $-0.001(.001)$ & & $0.001(.000)$ \\
Log employment & & $-0.046(.006)^{* *}$ & & $-0.042(.007)^{* *}$ \\
& & & & 10,036 \\
No. of observations & 15,497 & 14,179 & 2,816 & 2,748 \\
No. of major increases & 3,646 & 3,536 & 0.106 & 0.118 \\
Pseudo R-squared & 0.203 & 0.214 & & 0.228 \\
F-test of joint significance & & & 0.510 & \\
$\begin{array}{l}\text { of operating margin } \\
\text { coefficients (Prob. value) }\end{array}$ & 0.917 & 0.735 & & \\
\hline
\end{tabular}

Note: probit of the occurrence of major increase in the regulatory index during a given firm-year. The samples are drawn from the operating margin sample and are limited to observations in the industries linked to the ten largest titles in the CFR (see text and Appendix A1). Columns 3 and 4 restrict the sample further to those events and industries that represent a substantive change in regulation for the affected industry. Standard errors in parentheses. ${ }^{* *}=$ significant at $1 \%$ level; $*=$ significant at $5 \%$ level. All regressions include year dummies and dummies for 1-digit SIC industries; industry coefficients are jointly highly significant. 
Table 6. Difference-in-differences on Major Increases in Regulation, pooled panels

\begin{tabular}{|c|c|c|c|c|c|}
\hline Sample & All & & Substantive & or industry & \\
\hline Dependent variable & Operating margin & Operating margin & Operating margin & Residual & Residual \\
\hline Control group & $\begin{array}{l}\text { Firms without } \\
\text { major change }\end{array}$ & $\begin{array}{l}\text { Firms without } \\
\text { major change }\end{array}$ & All public firms & $\begin{array}{l}\text { Firms without } \\
\text { major change }\end{array}$ & $\begin{array}{l}\text { Firms without } \\
\text { major change, } \\
\text { propensity score } \\
\text { weighted }\end{array}$ \\
\hline Control firms & 3,237 & 1,854 & & 1,854 & 1,854 \\
\hline Treatment firms & 3,960 & 3,090 & 3,090 & 3,090 & 3,090 \\
\hline Difference before & $-0.023(0.012)^{*}$ & $-0.011(0.013)$ & $-0.047(0.012)^{* *}$ & $-0.039(0.011)^{* *}$ & $-0.048(0.007)^{* *}$ \\
\hline Difference after & $0.040(0.016)^{* *}$ & $0.071(0.017)^{* *}$ & $0.025(0.015)$ & $0.020(0.015)$ & $0.008(0.007)$ \\
\hline Difference in differences & $0.063(0.011)^{* *}$ & $0.081(0.011)^{* *}$ & $0.071(0.009)^{* *}$ & $0.059(0.011)^{* *}$ & $0.056(0.010)^{* *}$ \\
\hline Pre-event trend difference & $0.142(0.087)$ & $0.022(0.024)$ & $0.030(0.024)$ & $0.005(0.024)$ & \\
\hline No. of observations & 28,338 & 19,523 & 12,453 & 19,494 & 19,159 \\
\hline
\end{tabular}

Note: Standard errors in parentheses are calculated by block bootstrapping by firm with 200 repetitions. $* *=$ significant at $1 \%$ level; $*=$ significant at $5 \%$ level. The samples are pooled panels of firms in the treatment and control groups for three years prior to a major regulatory change and three years after. The first column includes all selected events; the other columns include only events where the regulatory history indicated a major substantive change affecting the relevant industry (see Table A1). The pre-event trend is the the change between three years before and one year before the event; the table reports the difference in this change between the treatment and control groups. Columns 4 and 5 use a residual from the regression in Column 1 of Table 3 as the dependent variable in the DID analysis. 
Figure 1. Log Tobin's Q

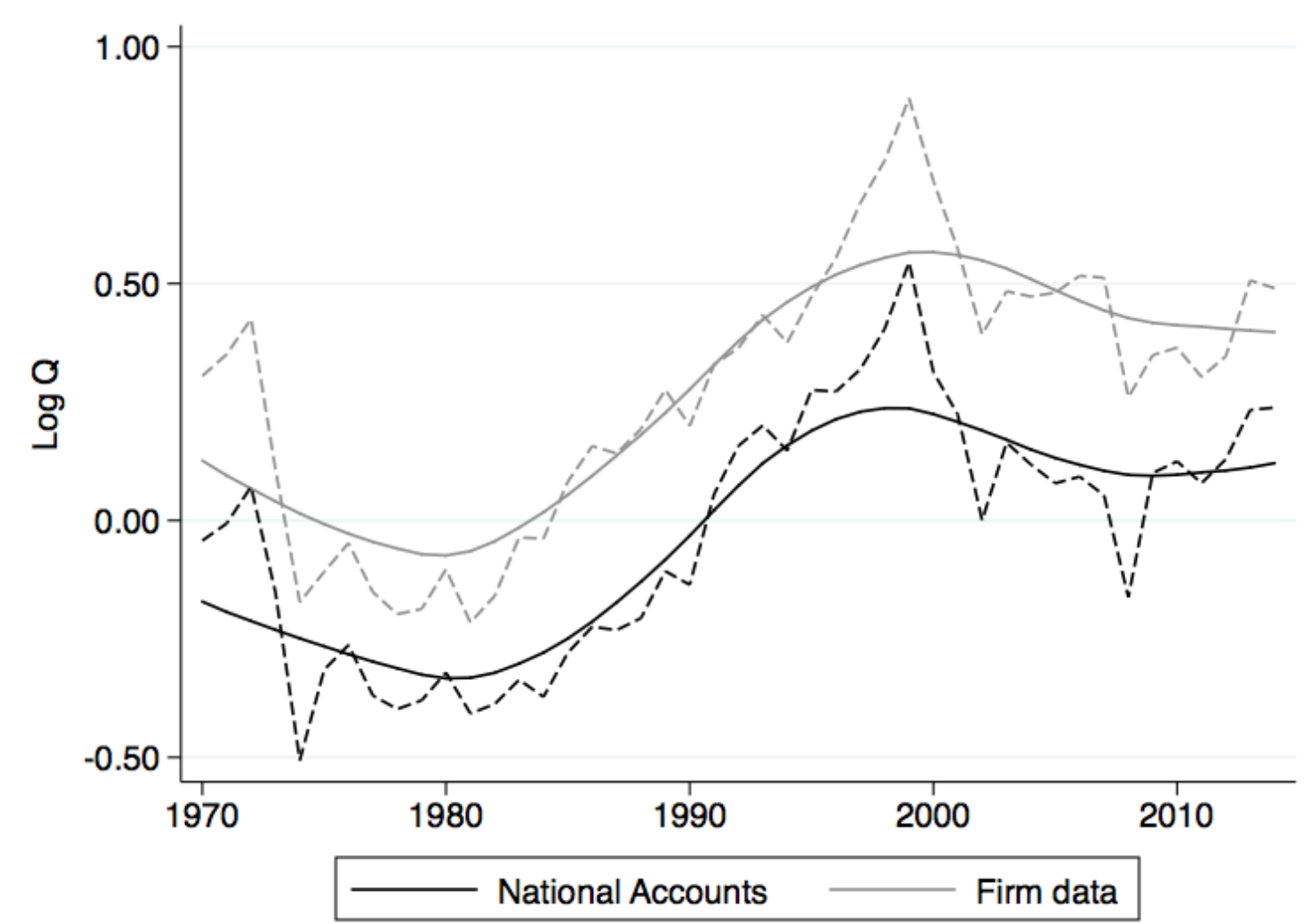

Note: Solid lines are kernel smoothed. Black line is aggregate firm value (total liabilities + inventories - current assets) over firm assets (nonfinancial assets excluding intellectual property products plus equity and investment fund shares) for the nonfinancial corporate sector, using data from the System of National Accounts, Bureau of Economic Analysis, http://www.bea.gov/national/nipaweb/Ni_FedBeaSna/Index.asp. Gray line is from Compustat data for non-financial firms, sample and variables described in the text. 
Figure 2. Operating Margins

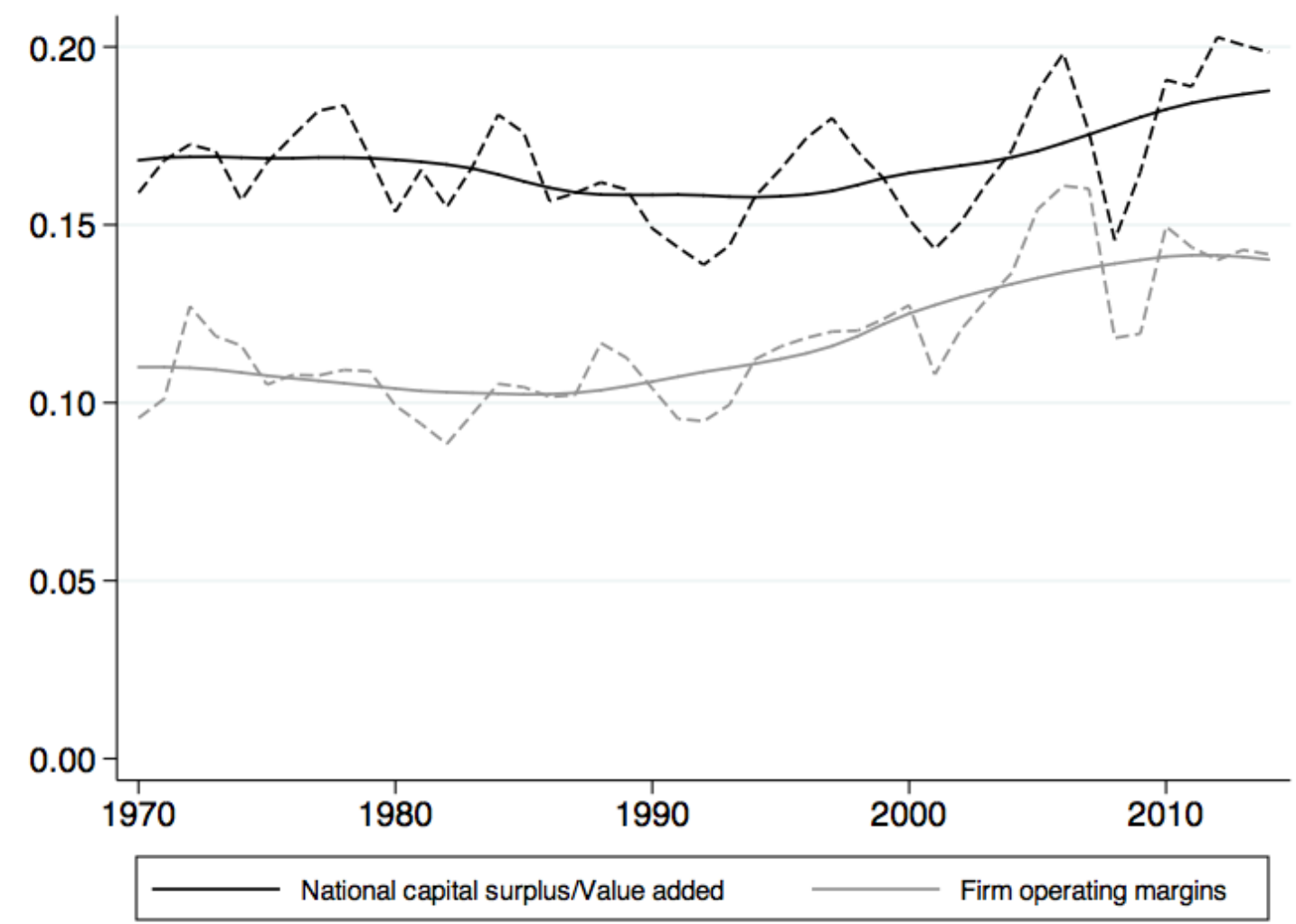

Note: Solid lines are kernel smoothed. Black line is from the System of National Accounts, Bureau of Economic Analysis. It shows the ratio of the net operating surplus to gross value added for the corporate sector (nonfinancial and financial). The gray line is the ratio of aggregate operating income after depreciation before taxes to revenues for firms publicly listed in the US. 
Figure 3. Words in Title 12, Banks and Banking, weighted by relevance to NAICS industry 522, Credit Intermediation and Related Activities

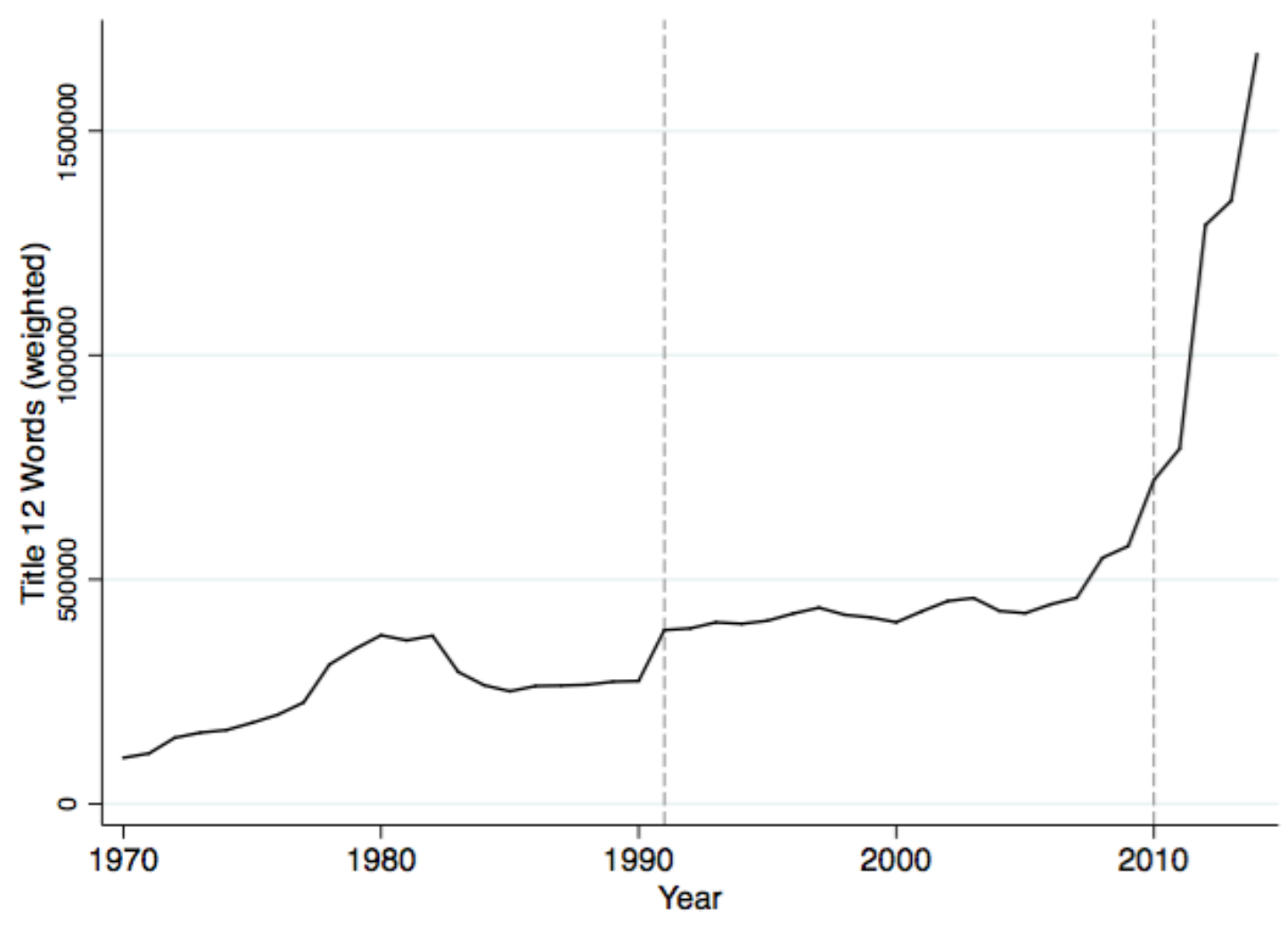




\section{Appendix. Tobin's Q equation}

I adapt a simplified version of Hayashi (1982) to incorporate multiple capital stocks where the aggregate capital stock, $K$, is a linear combination of different types of capital stocks, $k_{i}$,

$$
K(t)=\sum_{i} \gamma_{i} k_{i}(t)
$$

The $\gamma_{i}$ coefficients represent the relative profit-generating potential of different types of capital (Hall 1993). Let $i=0$ represent tangible capital and normalize $\gamma_{0}=1$. Assuming for simplicity that firms optimize variable inputs at each point in time and the production function has constant returns to scale, operating profits can be written as a linear function of aggregate capital, $\pi(K(t))=\alpha K$.

Investments in each type of capital, $x_{i}$, do not translate directly into increases in the capital stock because of adjustment costs. Adapting Hayashi,

$$
\dot{K}=G\left(x_{0}, x_{1}, x_{2}, \ldots, K ; t\right)-\delta K
$$

where $\delta$ is the depreciation rate and $G$ is linear homogeneous. The dynamic optimization problem is to maximize firm value, assumed to be the present value of future net profits,

$$
V=\int_{0}^{\infty}\left(\pi(K ; t)-\sum_{i} p_{i} x_{i}\right) e^{-r t} d t
$$

subject to constraint (A2), where $p_{i}$ is the price of investment good $i$ And $r$ is the discount rate. The present value Hamiltonian is

$$
H\left(x_{0}, x_{1}, x_{2}, \ldots, K ; t\right)=\pi(K ; t)-\sum_{i} p_{i} x_{i}+\lambda\left(G\left(x_{0}, x_{1}, x_{2}, \ldots, K ; t\right)-\delta K\right)
$$

and the necessary conditions for a maximum are:

$$
\begin{aligned}
& \frac{\partial H}{\partial x_{i}}=-p_{i}+\lambda \frac{\partial G}{\partial x_{i}}=0, \\
& \frac{\partial H}{\partial K}=\frac{\partial \pi}{\partial K}+\lambda \frac{\partial G}{\partial K}-\lambda \delta=-\dot{\lambda}+r \lambda, \text { and }
\end{aligned}
$$




$$
\lim _{t \rightarrow \infty} \lambda(t) K(t) e^{-r t}=0 \text { (transversality condition) }
$$

Note that because $G$ is homogenous of degree 1,

(A6) $G=\frac{\partial G}{\partial K} K+\sum_{i} \frac{\partial G}{\partial x_{i}} x_{i}$

Using the above, with some manipulation,

(A7) $\frac{d}{d t}\left(\lambda K e^{-r t}\right)=(\dot{\lambda} K+\lambda \dot{K}-\lambda K r) e^{-r t}=\left(-\pi+\sum_{i} p_{i} x_{i}\right) e^{-r t}$

Taking the integral of (A7) with respect to $t$ from 0 to infinity and using the transversality condition gives

(A8) $-\lambda(0) K(0)=\int_{0}^{\infty}\left(-\pi+\sum_{i} p_{i} x_{i}\right) e^{-r t} d t$

Following Hayashi, marginal $q \equiv \lambda / p_{0}$, so that

(A9) $\quad V(t)=\lambda(t) K(t)=q(t) p_{0}(t) \sum_{i} \gamma_{i} k_{i}(t)$

or Tobin's average Q is (using $t$ as a subscript as in the text)

$$
Q_{t} \equiv \frac{V_{t}}{p_{0 t} k_{0 t}}=q_{t}\left(1+\gamma_{1} \frac{k_{1 t}}{k_{0 t}}+\gamma_{2} \frac{k_{2 t}}{k_{0 t}}+\cdots\right)
$$




\begin{tabular}{|c|c|c|c|c|c|c|c|c|c|c|c|c|c|c|c|c|}
\hline & $\begin{array}{l}\text { 巳్. } \\
\text { 己. } \\
\text { ஜ }\end{array}$ & & 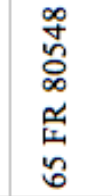 & 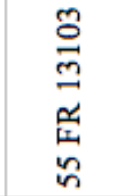 & \begin{tabular}{l} 
J \\
$\stackrel{\Xi}{\vec{J}}$ \\
㟔 \\
\multirow{2}{*}{}
\end{tabular} & 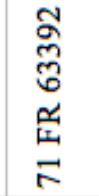 & 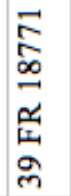 & & & & & & 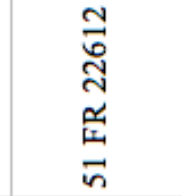 & 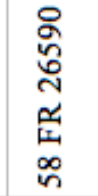 & 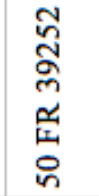 & 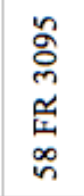 \\
\hline & 苋 & 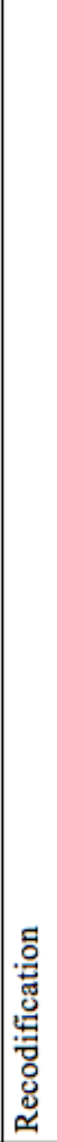 & 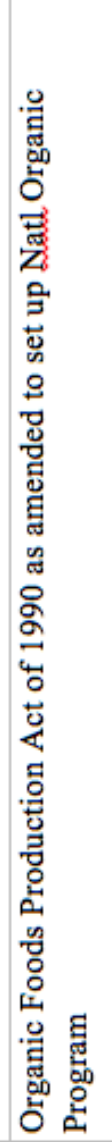 & 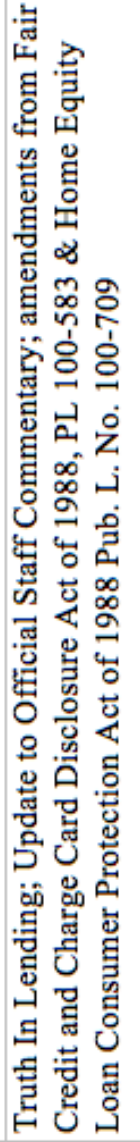 & 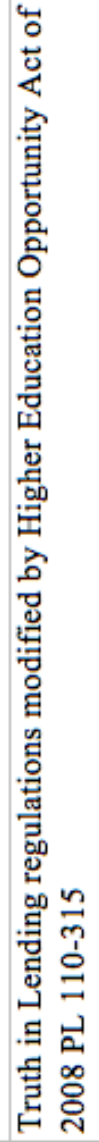 & 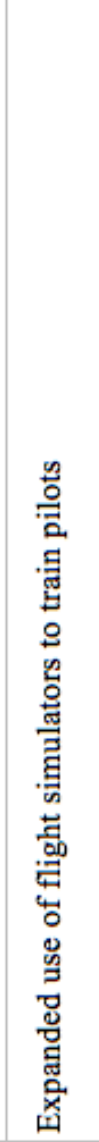 & 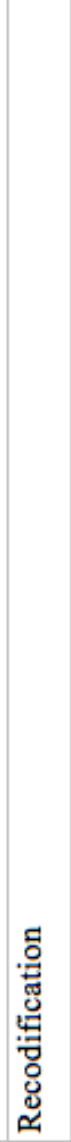 & 1 & 1 & 1 & 1 & 1 & 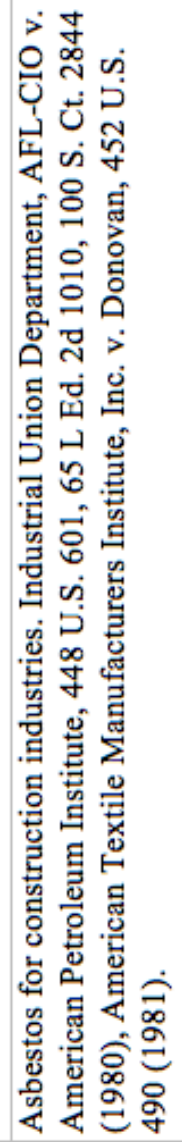 & 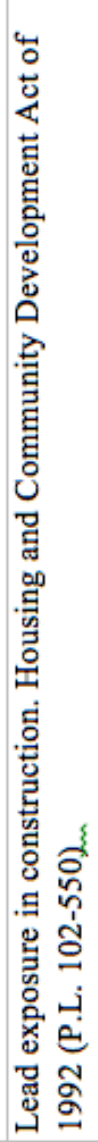 & 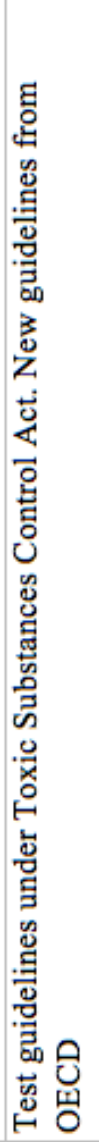 & 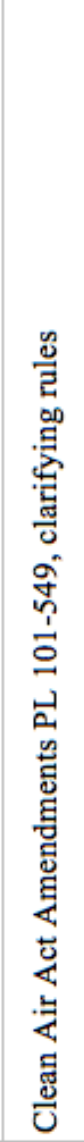 \\
\hline & 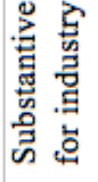 & 0 & - & $\rightarrow$ & - & 0 & 0 & 0 & 0 & 0 & 0 & 0 & - & - & - & - \\
\hline 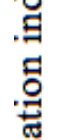 & 氶 & 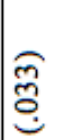 & 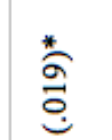 & $\stackrel{\text { * }}{\stackrel{*}{\tilde{*}}}$ & $\stackrel{\stackrel{*}{*}}{\stackrel{*}{\sigma}}$ & 官 & $\stackrel{\text { * }}{\stackrel{*}{\sigma}}$ & 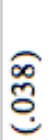 & $\stackrel{\stackrel{9}{\leftrightarrows}}{\stackrel{S}{g}}$ & త્ઞ & तู & $\stackrel{6}{=}$ & $\stackrel{*}{\stackrel{*}{\circ}}$ & క్ & 웅 & $\stackrel{*}{\stackrel{*}{\circ}}$ \\
\hline 呇 & 音 & 年 & ల్గ & $\stackrel{\infty}{=}$ & $\underset{\stackrel{\overbrace{}}{0}}{\stackrel{0}{0}}$ & $\begin{array}{l}\stackrel{\circ}{\circ} \\
\circ \\
\circ\end{array}$ & ָ̊ & 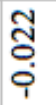 & $\frac{9}{0}$ & $\begin{array}{l}\infty \\
\text { ò } \\
\text { ị }\end{array}$ & \begin{tabular}{l}
$\infty$ \\
\multirow{0}{0}{} \\
$\stackrel{1}{1}$
\end{tabular} & 守 & 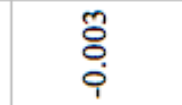 & 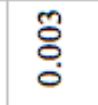 & 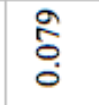 & $\begin{array}{l}\stackrel{0}{0} \\
\circ \\
0\end{array}$ \\
\hline \&్ర & 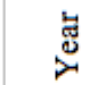 & 亏 & 홍 & 亏 & 응 & 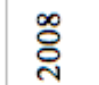 & 莺 & 尽 & $\begin{array}{l}\mathscr{2} \\
\infty\end{array}$ & ๙ & $\stackrel{\infty}{\stackrel{2}{2}}$ & §్̊․ & $\stackrel{\circ}{\stackrel{\circ}{二}}$ & ๙ૂ & 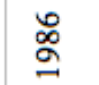 & ૂू \\
\hline $\begin{array}{l}\text { 명 } \\
\overrightarrow{0}\end{array}$ & 导 & $\vec{m}$ & $\vec{m}$ & กี & สี & $\stackrel{\infty}{v}$ & 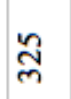 & กิ & กิ & กิ & సิ & กิ & $\overrightarrow{\mathrm{N}}$ & $\overrightarrow{\mathrm{N}}$ & ते & $\stackrel{\text { }}{\text { ñ }}$ \\
\hline 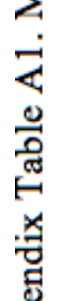 & 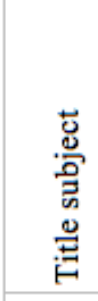 & 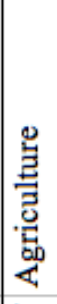 & $\begin{array}{l}\text { 莺 } \\
\text { 总 } \\
\text { 总 }\end{array}$ & 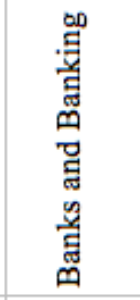 & 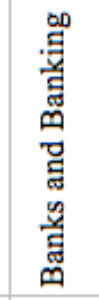 & 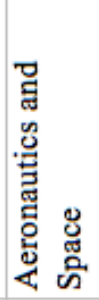 & 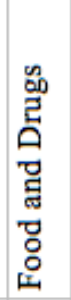 & 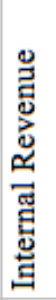 & 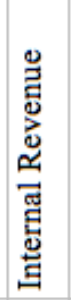 & 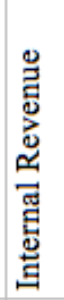 & 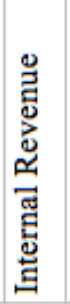 & 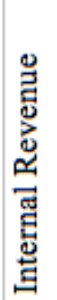 & 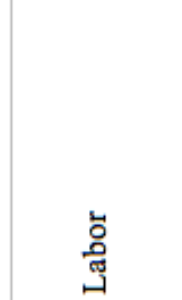 & 岑 & 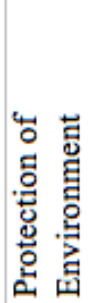 & 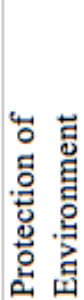 \\
\hline 产 & $\stackrel{\text { 总 }}{ }$ & r & $r$ & $\simeq$ & $\approx$ & $\Xi$ & $\vec{\sim}$ & ㄱ. & $\stackrel{\sim}{\sim}$ & i & $\stackrel{\sim}{N}$ & లి & নิ & নి & 웅 & 웅 \\
\hline
\end{tabular}




\begin{tabular}{|c|c|c|c|c|c|c|c|c|c|}
\hline 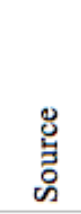 & 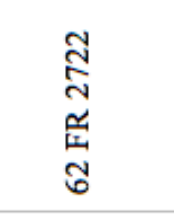 & 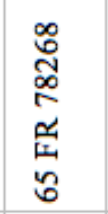 & 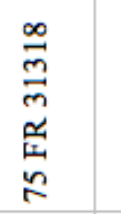 & & 吱 & & 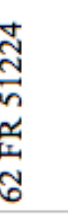 & 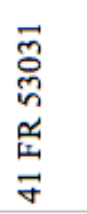 & \\
\hline$\frac{\mathrm{g}}{\mathrm{z}}$ & 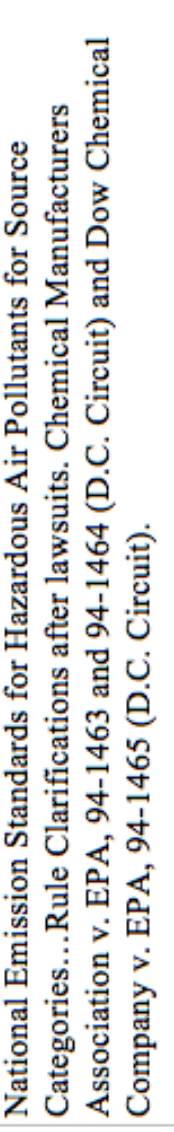 & 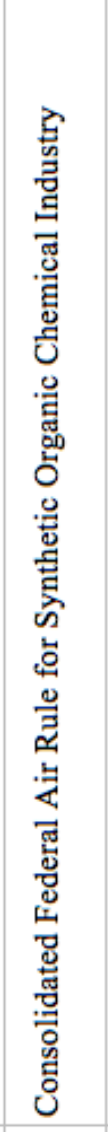 & 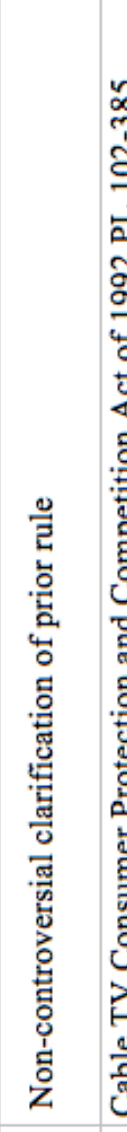 & 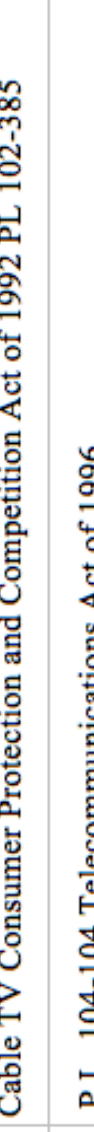 & $\begin{array}{l}0 \\
0 \\
0 \\
0\end{array}$ & $\frac{5}{3}$ & 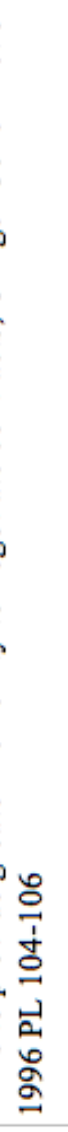 & 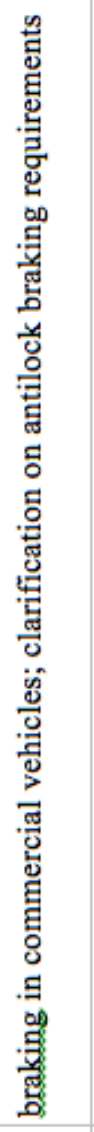 & 窇 \\
\hline 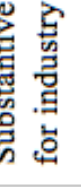 & - & - & 0 & - & - & 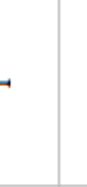 & - & - & - \\
\hline 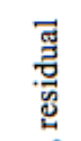 & 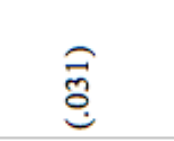 & 䓂 & 言 & 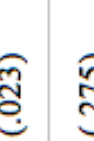 & ฮ્ّ & 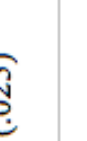 & 曾 & 萨 & శ్ \\
\hline$\hat{\mathrm{a}}$ & 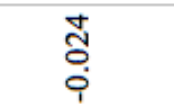 & $\stackrel{0}{0}$ & $\stackrel{8}{0}$ & 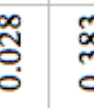 & ळ̆ & 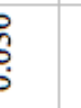 & 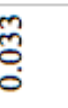 & 㺃 & 商 \\
\hline 总 & ఏ & ప্ন & 号 & : & $\stackrel{\alpha}{\alpha}$ & 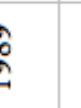 & $\Phi$ & 丽 & ڤ్ \\
\hline $\begin{array}{l}0 \\
\frac{0}{3} \\
\frac{n}{2}\end{array}$ & $\stackrel{్}{2}$ & 尺 & $\approx$ & $\underline{n}=$ & $\bar{F}$ & f & $f$ & 品 & 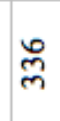 \\
\hline 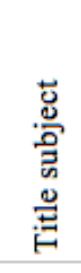 & 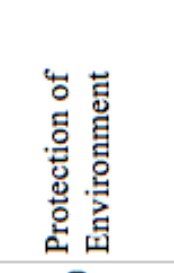 & 总善 & 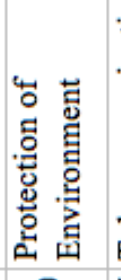 & & 崖 & & & & \\
\hline$\stackrel{0}{\stackrel{0}{*}}$ & 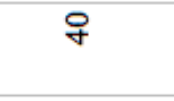 & q & & & & & os & & \\
\hline
\end{tabular}

